
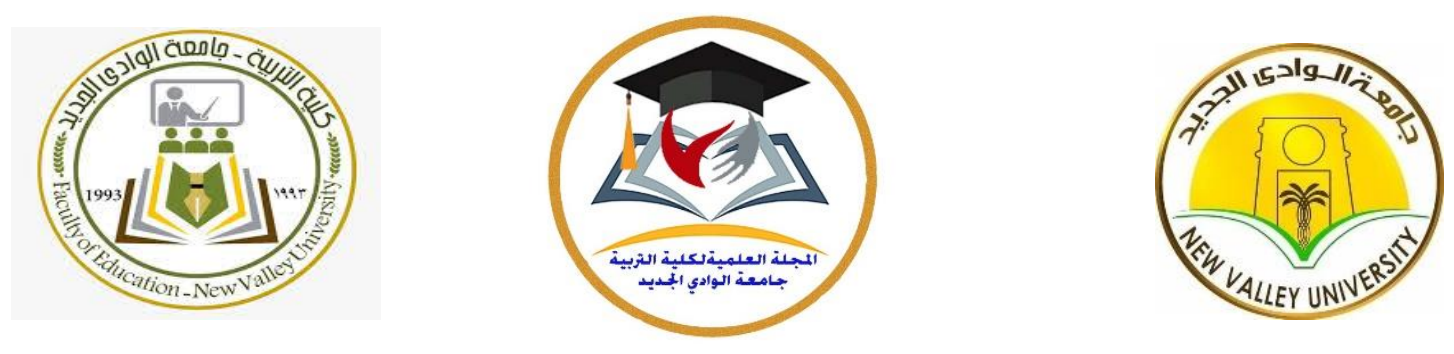

\title{
بحث بعنوان \\ معوقات الأنشطة الطلابية في المعاهد الثانوية الأزهرية \\ بالوادي الجديد لمواجهة ظاهرة التطرف
}

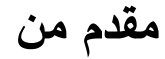 \\ أحمد عمر عبدالله آدم من معن \\ مدرس بمعهد الإيمان \\ المنطقة الأزهرية بالوادي الجديد
}

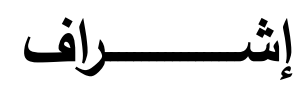

د/ محمد محمود الامنهوري

استاذ متفرغ بقسم أصول التربية

كلية التربية جامعة الوادي الجديد
أ.د/ أشرف محمد طه

أستاذ أصول التربية ووكيل كلية التربية لشئون الدراسات العليا والبحوث-جامعة الوادي الجديد

$$
\text { r. r. - D I } \leqslant \varepsilon .
$$




\section{مقدمة:}

يشغل التعليم عامة والتعليم الأزهري بصفة خاصة مكاناً بارزاً بين نظم التعليم وذلك لما يقع عليه من مسئولية الحفاظ على القيم الإسلامية، وإكساب الفرد سمات وصفات المواطن الصالح، حيث تعمل مضامينه على تتمية الثخصية الإنسانية في مختلف جوانب الحياة ، وتمثلت هذه الرسالة في حفظ القرآن الكريم، والأحاديث النبوية الثريفة، وما يتصل بهما من تعاليم دينية تحافظ على الأفراد والأسرة والمجتمع الإله

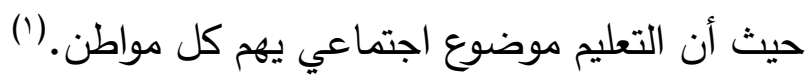
مما سبق يتضح أن التغلب علي المعوقات التي تحول علي تطبيق الانشطة الطلابية يعد ضرورة ملحة من أجل الحد من تلك المعوقات وفقا للإمكانيات المتاحة للحصول علي الثمرة المرجوة من خلال تقعيل الانثطة داخل المعاهد.

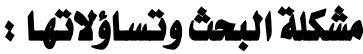

يعد الأزهر والتعليم الأزهري من المؤسسات المهمة والتي يقع عليها دور في تطوير العملية التعليمية ، وأن المكانة التي يحتلها تجعله في مكانة تستدعي الدراسة والتحليل والوقوف على المعوقات التي تواجه تفعيل الانشطة الطلابية بالمعاهد الأزهرية للهوض به، ولن يحدث ذلك إلا إذا استعاد الأزهر قوته ومكانته والسبيل لذلك هو تطوير التعليم الأزهري والنهوض به وذلك عن طريق تفعيل الانشطة الطلابية بالمعاهد الأزهرية من خلال التعرف علي التحديات والمستجدات التي تواجه التعليم الأزهري والوقوف على سبل التطوير النلام للتعليم الأزهري بجميع مراحله ولاسيما المرحة الثانوية. - ومن خلال عمل الباحث في المعاهد الأزهرية بالوادي الجديد لاحظ قصور في تفعيل الانثطة الطلابية نظراً لقلة مشرفي النشاط وكذلك قلة الامكانيات المتاحة سواء مادية أومن خلال تجهيز الابنية والمساحات التي تقام من أجل ممارسة الانثطة الطلابية كما لاحظ الباحث قلة الميزانية المخصصة للممارسة تلك الانشطة، مما أدى إلى بعض المعوقات في تفعيل الانشطة، كما أن عدم استثمار أوقات الفراغ قد يجعل هناك بيئة خصبة للانحراف(r) هذا ما أكدت عليه دراسة (عبد الحميد عبد المحن،

(r) $(ه) \leq \cdot V$

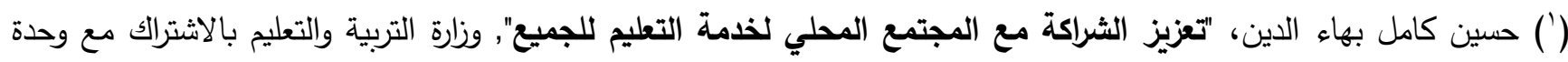

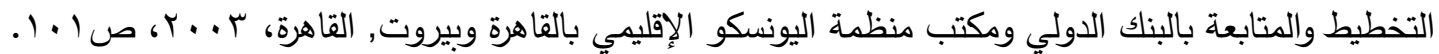

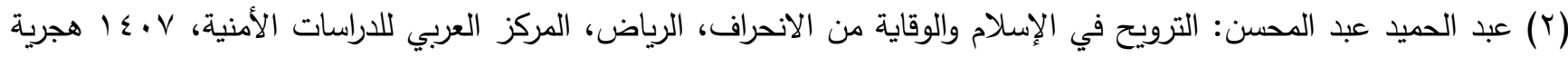


وفي ضوء ما تقدم تأتي الدراسة للوقوف علي المعوقات التي تواجه الانثطة الطلابية لتطوير العملية التعليمية بالمعاهد الأزهرية بالوادي الجديد.

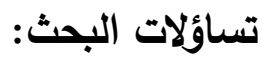

1- ما الإطار الفكري والفلسفي للأنشطة الطلابية؟ r- ما واقع الانثطة الطلابية في المعاهد الأزهرية بالوادي الجديد؟ r- ما التوصيات والمقترحات التي تسهم في التغلب على المعوقات التي تواجه الانثطة الطلابية بالمعاهد الأزهرية لمواجهة ظاهرة التطرف بالوادي الجديد؟ الاراسات السابقة:

\section{أولاً - الدراسات العربية:}

دراسة ( وليد الخراشي، ؛ . . ب) التي توصلت إلى أن الأنثطة الطلابية لها تأثير في تتمية

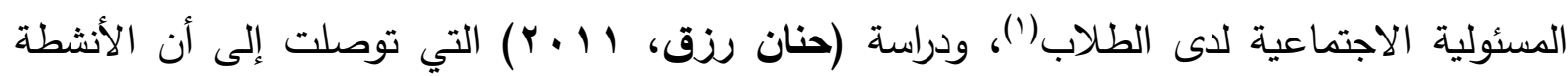

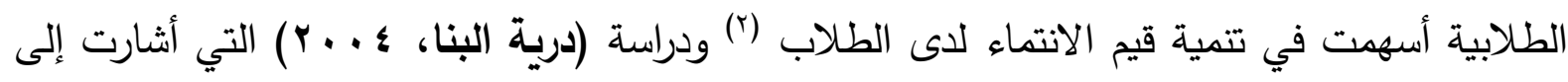

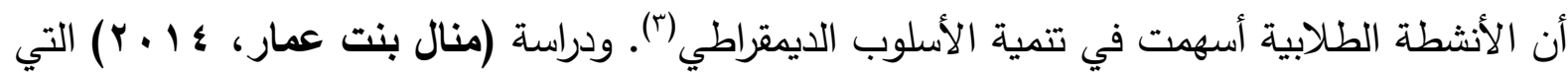

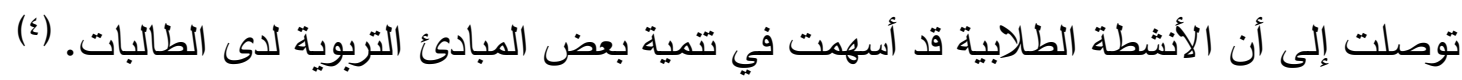
ثانياً: الاراسات الأجنبية:

دراسة (2015, Dagmar .M \& Tino W) والتي توصلت إلي أن الانشطة الطلابية تعد بأنها تلك البرامج التي تتفذ بإشراف المدرسة وتوجيهها، والتي تتاول كل ما يتصل بالحياة المدرسية وأنشطتها

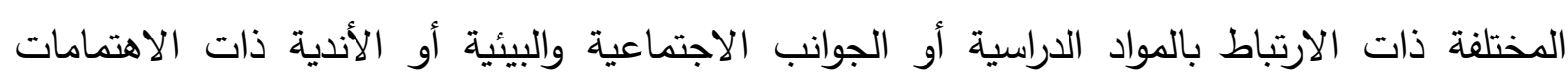

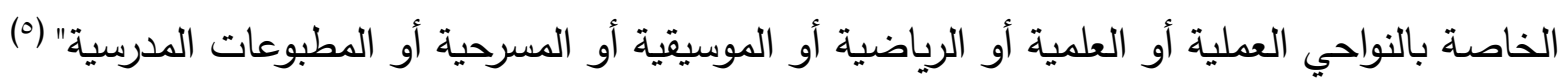
(1) وليد بن عد العزيز يعد الخراشي، دور الأنشطة الطلابية في تنمية المسؤولية الاجتماعية، رسالة ماجستير، كلية الآداب، عمادة

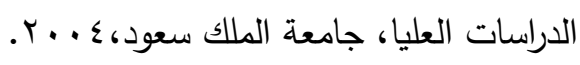

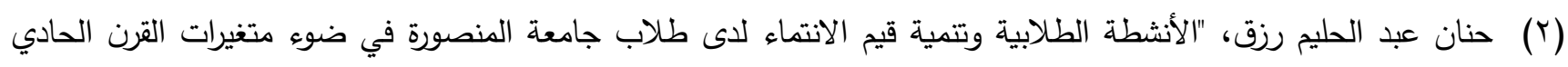

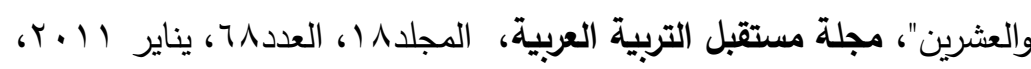

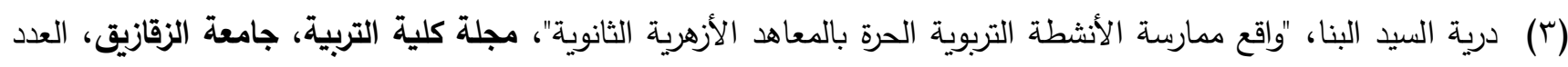
海

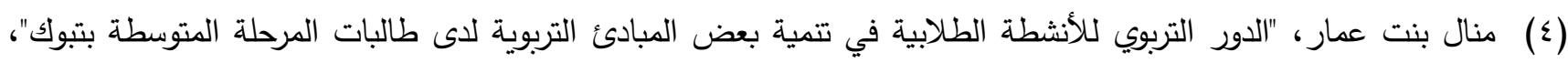

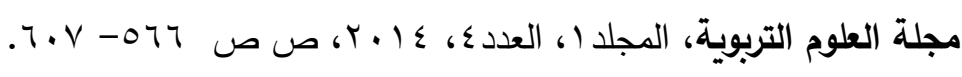
(5)Dagmar .M \& Tino W(2015). Evolving Lesson Plans to Assist Educators: From Paper-Based to Adaptive Lesson Planning, Journal of Health, Population and Nutrition, Vol. 28, No 6. 


\section{التقيبي علي الدراسات السابقة:}

نظرًا لأهمية الدراسات السابقة بالنسبة للدراسة الحالية، والاستفادة منها سواء في الجانب النظري والميداني، حيث تتاولت بعض الجوانب المختلفة والمتصلة بموضوع الدراسة الحالية. فهناك الكثير من الدراسات العربية والأجنبية التي تتاولت معوقات الانثطة الطلابية في البيئات التعليمية المختلفة، مما لهابل يثير أن هناك اهتماما متزايدا في الكثير من الدراسات التي تثير إلي اهمية الانثطة الطلابية ومعرفة المعوقات ومحاولة التغلب علي تلك المعوقات.

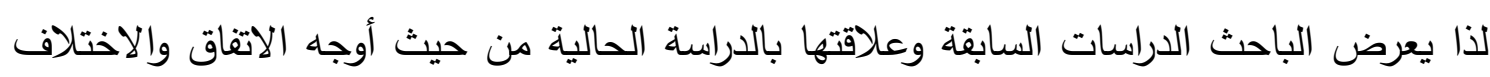

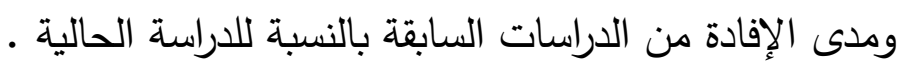

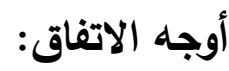

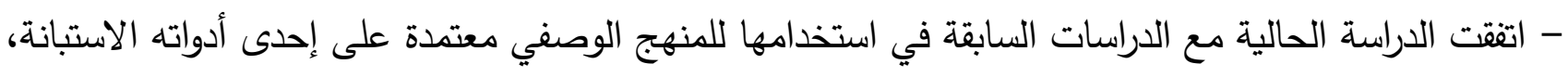

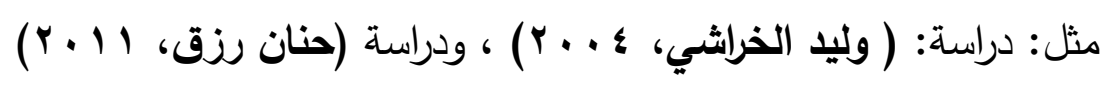

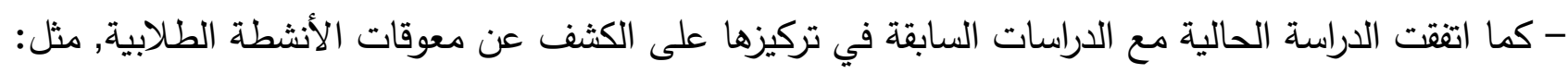

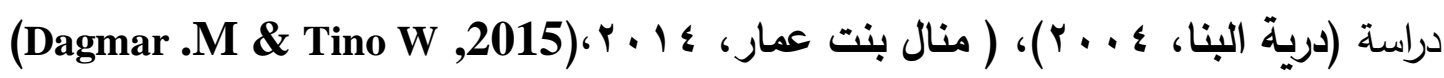
أوجه الاختلاف:

- اختلفت الدراسـة الحالية عن الدراسـات السـابقة في العينة حيث كانت عينـة الدراسـة الحالية من طلبة المعاهد الثانوية الأزهرية أما الدراسات السابقة فقد أجريت على طلاب التعليم العام.

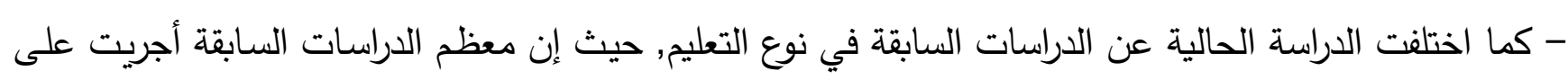
التعليم العام, أما الدراسة الحالية فقد أجريت على التعليم الثانوي الأزهري. أفادت الاراسة الحالية من الدراسات السابقة في الاتي:

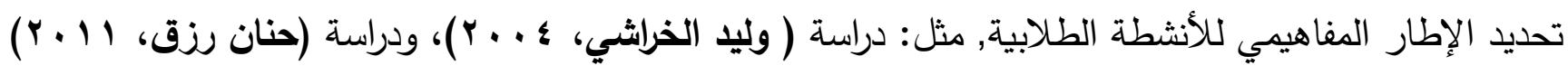
- التعرف على أسباب ومظـاهر التطرف لدى طـلاب المرحلة الثانويـة التي لها تأثير على العملية التعليميـة،

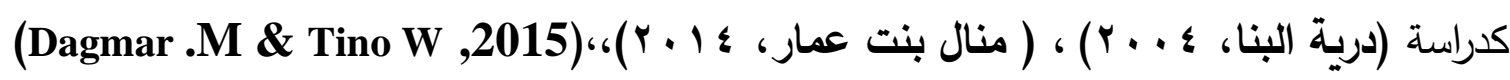
- أفادت الدراسة الحالية من الدراسات السابقة في تحديد جوانب الدراسة الميدانية والمتمثلة في المنهج الوصفي التحليلي وأداته الاستبانة؛ لتحديد معوقات الأنشطة الطلابية. - أفادت الدراسة الحالية من الدراسات السابقة في تقسير نتائج الدراسة الميدانية . 
1-التعرف علي الإطار الفكري والفلسفي للأنشطة الطلابية. r-الوقوف علي واقع الانشطة الطلابية في المعاهد الأزهرية بالوادي الجديد. r-التوصل إلى بعض التوصيات والمقترحات التي تسهم في التغلب على معوقات ممارسة الانثطة

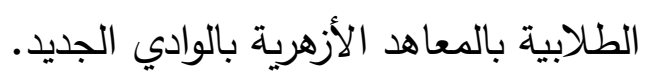

\section{أهية البعث:}

- تقيد الدراسة القائمين على تطوير التعليم الأزهري في التعرف على معوقات الانشطة الطلابية بالمعاهد الأزهرية بالوادي الجديد.

- قد تفيد الدراسة المهتمين بقضايا التعليم الأزهري في صياغة حلول للمشكلات التي تواجه المعاهد الأزهرية بالوادي الجديد. من ظاهرة التطرف.

- - المساهمة في تعميق وعى الطلاب بأهمية ممارستهم للأنثطة الطلابية. - - تضضح أهمية الدراسة من خطورة التطرف على أمن وسلامة المجتمع واستقراراه، وما يعانيه المجتمع في الآونة الأخيرة من تفثي ظواهر التطرف والعنف والإرهاب. - - المساهمة في إثراء البحث العلمي بتزويد الباحثين بأداة علمية مضبوطة وبرنامج تطبيقي مقترح في مجال الأنثطة الطلابية. مصطلحات البحث :

\section{الانثطة الطلابية :}

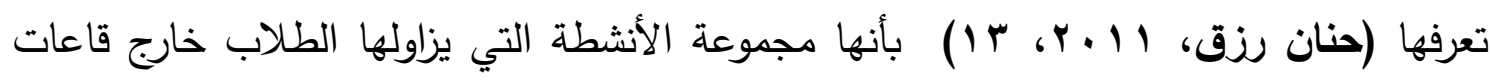
الدرس الرسمية في مختلف المجالات الدينية والثقافية والفنية والاجتماعية والرياضية والتي تستهدف

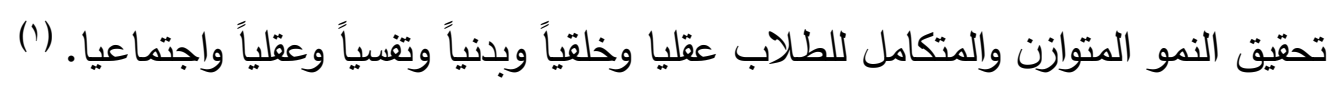


يعرفها ( حسن شحاتة، 919 19، هـ) بأنها مجمل البرامج والأنشطة التي يمارسها الطلاب داخل الدرسة أو خارجها وفق ميولهم واستعداداتهم وقدراتهم وحسب الإمكانيات المتاحة لهم والتي ترتبط

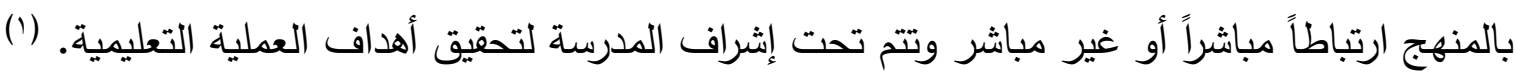
كما يعرفها كل من (Dagmar .M \& Tino W ,2015) بأنها تلك البرامج التي تتفذ بإشراف المدرسة وتوجيهها، والتي تتتاول كل ما يتصل بالحياة المدرسية وأنشطتها المختلفة ذات الارتباط بالمواد التاديا

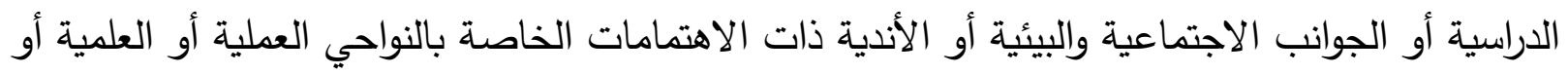

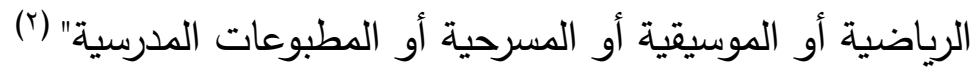

ومن خلال التعريفات السابقة يمكن تعريف الأنثطة الطلابية إجرائياً بأنها: مجمل الأنشطة المقصودة التي تتم داخل المدرسة أو خارجها والهادفة تربوياً والتي قد تسهم في الحد من ظاهرة التطرف. الإطار النظري للبحث: - مارجئ ويتتاول الأنشطة الطلابية والتطرف وذلك على النحو التالي:

أولاً: الأنثطة الطلابية:

1 ا ـ مفهوم الانثطة الطلابية:

أ- الانثطة الطلابية لغة:

نشط من المكان نشطاً: خرج، ويقال نشاط الميل خرج عن الجادة وذهب يمنة ويسرة، ونشطت به الهموم أزعجته وذهبت به الدذاه، ويقال أنثط فلانا: صيره نشيطاً، ونشيطاً فلانا جعله ينشط، ويقال

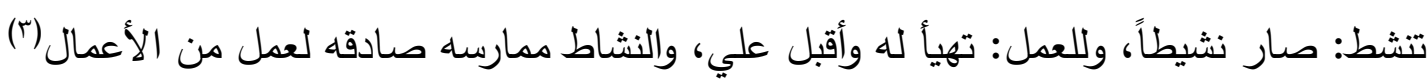

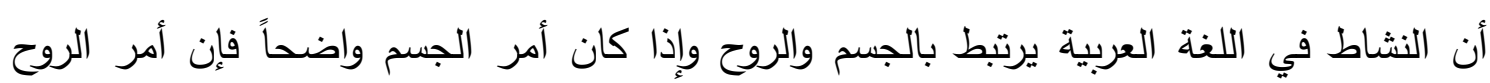

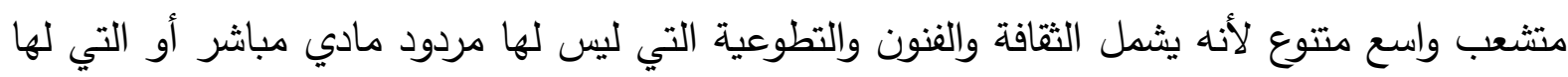

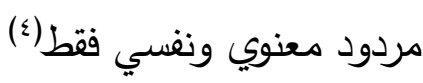
ب- الانثطة الطلابية اصطلاحاً: تعددت التعريفات التي دارت حول ماهية النشاط الطلابي وذلك على النحو التالي:

(') حسن شحاتة ، النشاط المدرسي( مفهومه ووظائفه ومجالات تطبيقه)، القاهرة ، الدار اللبنانية، 991 ( )، ص هץ. (2)Dagmar .M \& Tino: Evolving Lesson Plans to Assist Educators: From Paper-Based to Adaptive Lesson Planning, Journal of Health, Population and Nutrition,( 2015). Vol. 28, No 6.

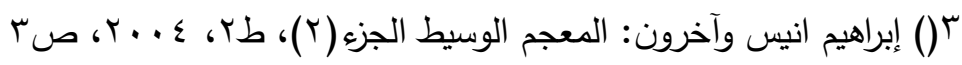

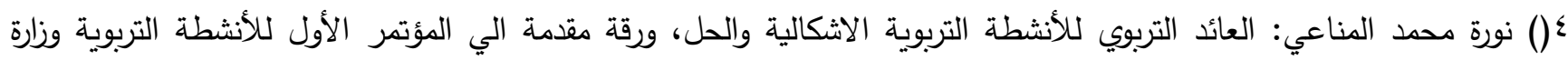

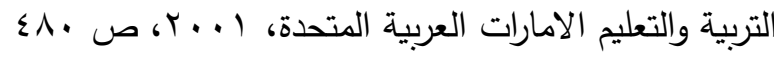


عرفها مصطفي عبد الحميد عناني بأنها هي كل ما يقوم به الطلاب من اعمال وما يمرون به من خبرات بطريقة حرة في المجالات الثقافية ولاجتماعية والرياضية والفنية وأنثطة المعسكرات والجوالة

والإشراف عليها (1)

كما عرفها توفيق قمر عصام، ورجاء محمود عثمان بأنها " أنماط التفاعل التي تتم خارج المؤسسة التعليمية والتي يشارك فيها الطلاب مشاركة فعلية، أو بمعنى آخر الاعمال التي تنظمها المؤسسة التعليمية لطلابها في غير قاعات الدرس كالرحلات والحفلات والالعاب الرياضية والهويات، وما إلى

ذذلك. (广)

ويمكن تعريف الانشطة الطلابية إجرائياً بأنها: تلك الممارسات الثقافية والاجتماعية والفنية المتتوعة التي يمارسها طلاب الجامعة من خلال اللجان المنبثقة عن الاتحادات الأنثطة الطلابية بطريقة حرة ومنظمة خارج نطاق الدراسة ويكون اتحاد الطلاب مسؤولا عنها وتقوم تلك اللجان المختلفة (الفنية، والثقافية، والرياضية، والاجتماعية، والجوالة والخدمة العامة والأسر ).

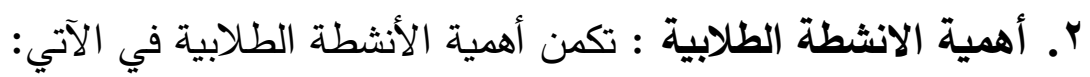
- النثاط الطلابي له أهمية بالغة لا تقل عن أهمية ما يحدث داخل القاعات الدراسية إذ أنه يعتبر وسيلة من الوسائل الفعالة لتحقيق الأهداف التربوية ويمكن تلخيص أهمية النشاط الطلابي فيما يلي:((). - تتمية المهارات الأساسية للتعليم الذاتي والمستمر وخاصة التي تتضمن قراءة الكتب والمراجع، وكتابة التقارير، والاشتراك في المناقشات المفيدة، كما أنها تنمى مهارات متصلة بالتطبيقات العلمية، ومهارات التفاهم الثفوي والكتابي، والتعامل الناجح وزيادة التحصيل الدراسي • - تتمية العلاقات الاجتماعية السليمة من خلال الخبرات العملية(؟)

() (مصطفي عبد الحميد عناني: تغعيل دور الأثنطة الطلابية بكليات التربية فتتمية قيم المواطنة العالمية - دراسة حالة، بجامعة

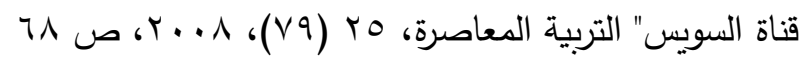

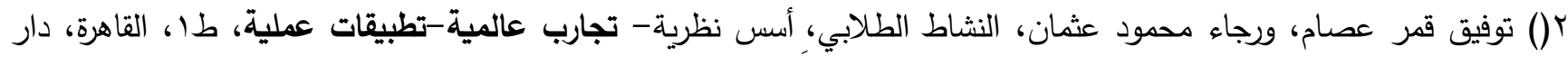

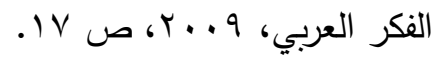
ץ (() حنان ثابت مدبولي: واقع الأنثطة الطلابية في الدارس الثانوية للبنات بمحافظة صامتة، مجلة كلية التربية، جامعة الأزهر،

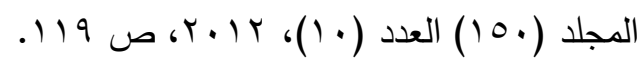
ك)( السعيد محمود السعيد: الأنثطة الطلابية ودورها في العطلية التربوية، حولية كلية المعلمين في أبها، جامعة الملك خالد، مركز

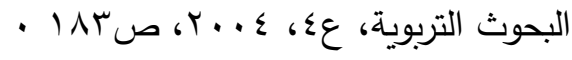


يهدف النشاط الطلابي إلى ('):

- معرفة مبادئ الإسلام وقيمه وآدابه واحكامه وترجمتها إلى واقع عملي في الحياة. - التعرف بإمكانيات الوطن والاعتزاز بها والمحافظة علي إنجازاته. كما ذكر فاروق البهوي أهداف الانشطة بانها تتمثل في الاتي(؟): - بناء الثخصية المتكاملة للطالب ليصبح مواطناً صالحاً يرتبط بوطنه ويعتز به. - تعديق قيم الدين الإسلامي وترجمتها إلى أفعال. - زيادة قدرة الطالب على التفاعل مع مجتمعه (التكيف الاجتماعي). - اكتثاف القدرات والمواهب والمهارات وتتميتها.

؛. مجالات الانشطة الطلابية: تتعدد مجالات الانشطة الطلابية وقد لخصتها حنان ثابت في الآتي:

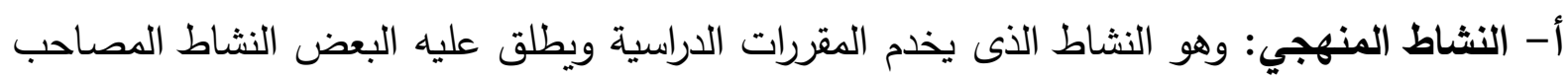
للمنهج(Co-curricular Activity) والنشاط المنهجي الإضافي (Extra-Curricular Activity) ويعد هذا التقسيم أساسياً لإتاحة الفرص المتعددة أمام الطلاب لاكتساب الخبرة بصورة طبيعية إيجابية . ب- النشاط غير المنهجي: وهو نشاط حر يتمم المقررات الدراسية ،ويعالج ما قد يكون فيها عجز أو الإسيه قصور ،ويسهم في محاربة الملل واكتساب الهوايات، واحترام العمل اليدوي وحل مشكلات وقت الفراغ، والتوجه الدراسي والمهني. كما تعددت المجالات وفقاً لما أشارت إلية الدراسات والبحوث التربوية ومنها: أ- مجال الانثطة الثقافية. ب- مجال الانثطة الاجتماعية. ج- مجال الانثطة العلمية. د- مجال الانشطة الرياضية. هـ مجال الانثطة الكثفية. 
ويمكن القول أن مجالات الانثطة الطلابية عديدة ومتتوعة وتنتح الأبواب لجميع فئات الهجتمع للمشاركة الحقيقية في العملية التعليمية سواء كانت المشاركة مادية أو إدارية أو بالمقترحات والأفكار البناءة التي تساهم في تطوير العملية التعليمية.

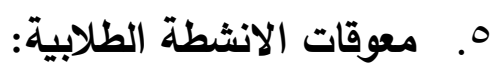

قد توصلت بعض الدراسات للعديد من المعوقات منها دراسة حسين 9. . . ب( (1) والتي أظهرت أهم المعوقات هو عدم توفر الإمكانات المادية والخامات، عدم توفر المكان المناسب والورش، وقلة وعي الطلاب بأهداف النشاط، ضيق الوقت، عدم توفر الموارد المالية المناسبة، قلة الحوافز , كما أضافت دراسة حجازي 10 ـ r،(r) أن من أهم الصعوبات التي تواجه أن فترة النشاط تكون دائماً في نهاية اليوم الدراسي، وأن أداء الطلاب واشتراكهم في الأنشطة غير الصفية لا يؤخذ في الحسبان عند التقويم النهائي لتحصيلهم الدراسي، وانشغال الطلاب بالاستذكار من بداية الفصل الدراسي عن الاشتراك في برامج •

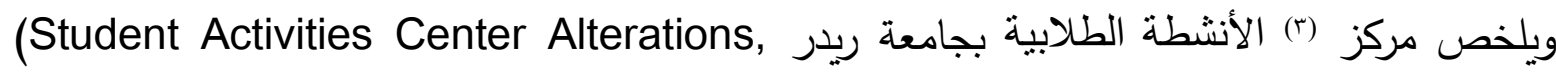
Rider University, Lawrenceville, New Jersey 2016) افتقارها لعناصر التشويق والمتعة والترفيه، وضعف عوامل الجذب، وكذا عدم ارتباط الأنثطة الصفية بالتحصيل الدراسي، كما لا توجد محفزات لتشجيع الطلاب على الاشتراك في الأنثطة. كما لخصت هذه المعوقات في النقاط التالية(؛):

قلة توفر الوقت الكافي لدى الطلاب لممارسة الأنشطة الطلابية لازدحام الجداول بالمواد الدراسية. لا يأخذ الطالب الحرية في اختيار الانشطة التي تناسب ميوله وتثبع حاجاته. - - - - ميادة محتوى المقررات الدراسية.

ضعف تأمين الخامات والأدوات الكافية لتنفيذ النشاط. - - مقلة توفر الأماكن الملائمة لممارسة النشاط. كما لخص خالد السبيعي هذه المعوقات في النقاط الاتية(ن):

( () الحسين حامد محمد حسين: التربوية وتتمية الوعي الوطني لاي تلاميذ التعليم الاساسي، رسالة ماجستير، كلية تربية، جامعة

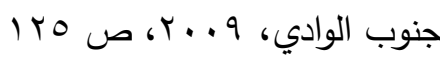

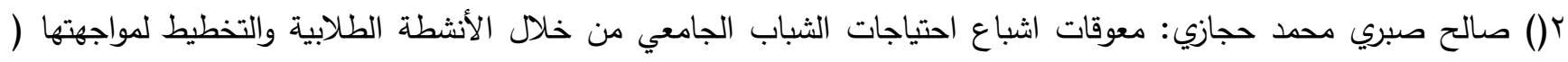

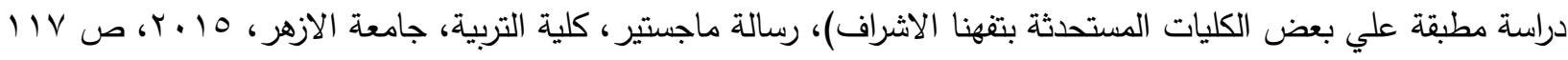
(3) Rider University Architects, Student Activities Center Alterations, University Architects, Lawrenceville, New Jersey,2016,p32.

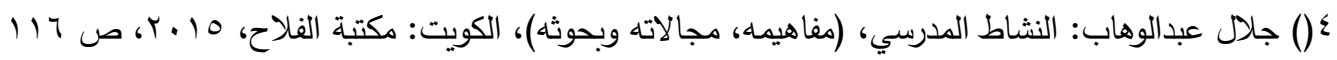

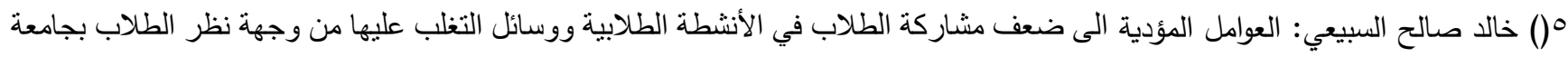




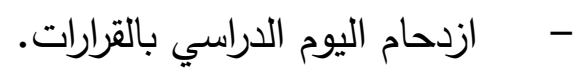

- - - - ملة الحوافز المادية أو المعنوية.

- - - مود منهج بشكل غير واضح ومحدد للأنشطة.

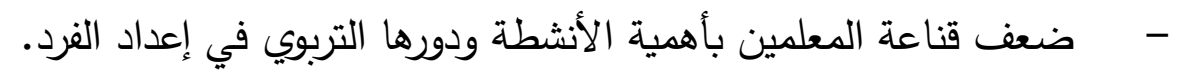

- - ل الخصص درجات للنشاط.

كما لخص تلاك المعوقات بدر العتيبي في النقاط الاتية (1).

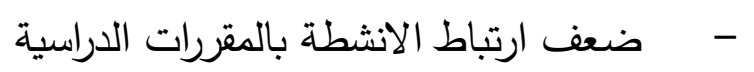

- - مقلة التعاون في الممارسة وتتفيذ الأنثطة المعاهد والمؤسسات الاجتماعية. وبين الأسر والمعاهد.

- - متعف التعاون في ممارسة وتتفيذ الأنثطة بين الطلاب أنفسهر.

- - ملة التعاون في ممارسة وتتفيذ الأنشطة بين الادارات والمعلمين.

- - ندرة المختصين المؤهلين للإشراف على الأنثطة ومتابعتها.

- - معف إدراك المعلمين لأسس ممارسة الأنشطة.

ثنانياً: التطرف:

1. ـ مفهوم التطرف

أ- التطرف لغة: التطرف لغويا أو معجميا من الفعل "طرف " و "تطرف" وله دلالات عدة بحسب

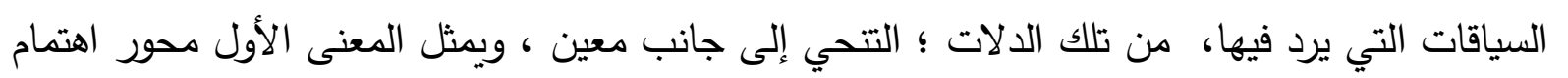

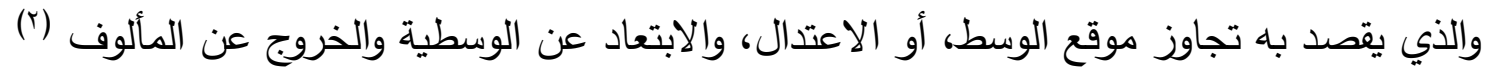

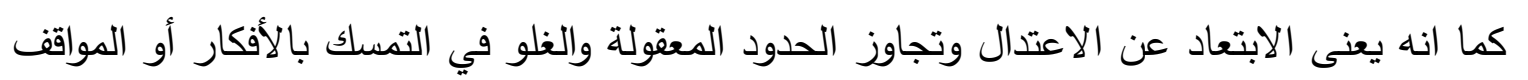

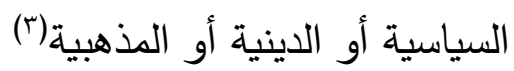

ومن التعريفات اللغوية السابقة يتضح ان لفظ تطرف مرتبط في جوهره بالانحراف عن الوسط سواء

كان بالغلو او الانقاص. وكذلك الميل إلي أحد الاطراف سوء يميناً أو يساراً.

$$
\text { ب- التطرف اصطلاحاً : }
$$

يعرف التطرف بأنه: استجابة تتحرف سلباً عن المتوسط، وهو ما يتجاوز حد الاعتدال، أو

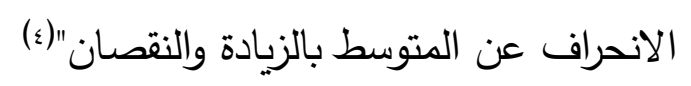

'() بدر العتيبي: معوقات المشاركة في الأنشطة لدى طلاب المرحلة الثانوية بالمدارس الثانوية في الددينة المنورة، دراسة تربوية واجتماعية، مج

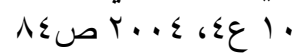

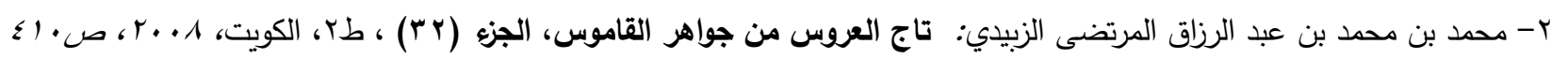

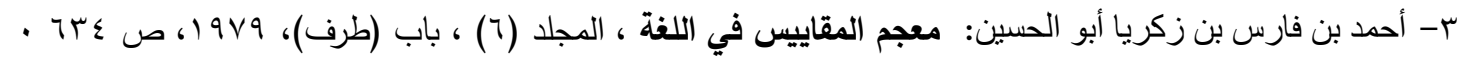

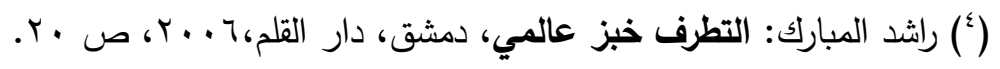




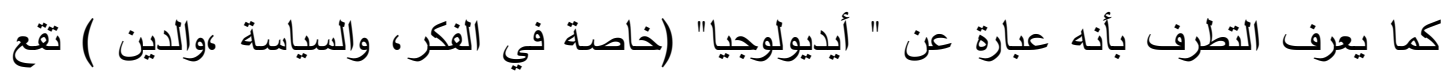
بعيداً عن الاتجاهات الرئيسة السائدة في المجتمع، أو تتعارض مع الئرة المعايير الاخلاقية المشتركة بين

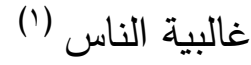

بينما يعرف التطرف بانه "اتخاذ الفرد موقفا متثددا يتسم بالقطيعة في بيئته التي يعيش فيها

هنا والآن وقد يكون التطرف إيجابيا في القبول التام، ويقع حد الاعتدال في منتصف المسافة بينهما (؟).

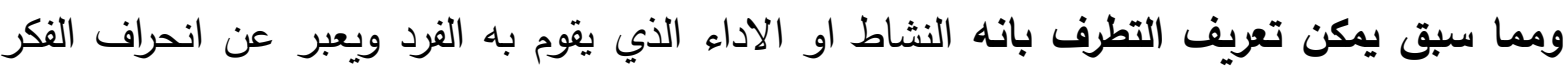

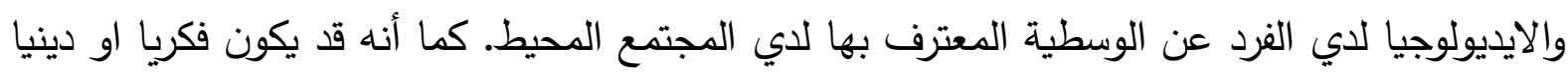

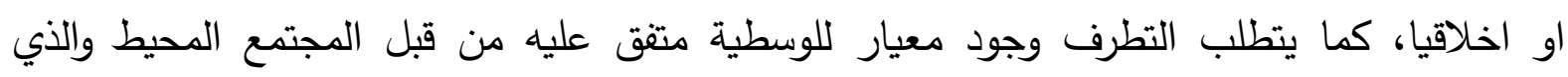
بالانحراف عنه زيادة او نقصانا يمكن اعتباره تطرفاً.

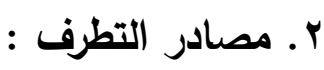

تعد مشكلة التطرف من المشكلات البارزة التي تشغل اهتمام الكثيرين من صناع القرار والمؤسسات

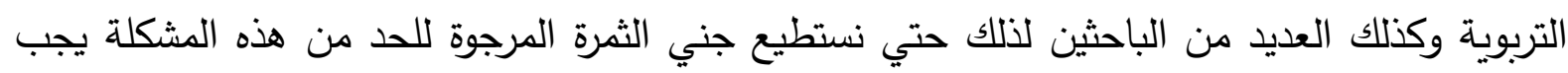
النظر إلي مصادر تلك الظاهرة حيث تتعد المصادر المؤدية للتطرف فيمكن تقسيمها على النحو التالي:

أ- التطرف نتاج البيئة :

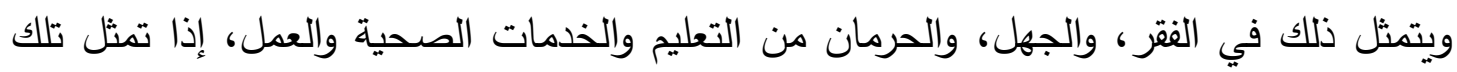

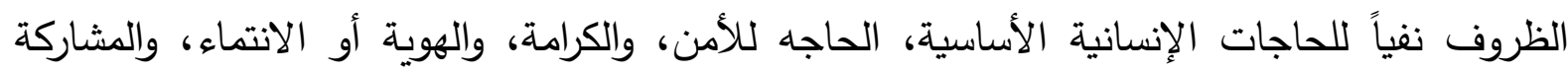

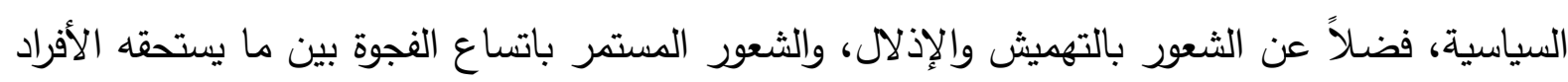

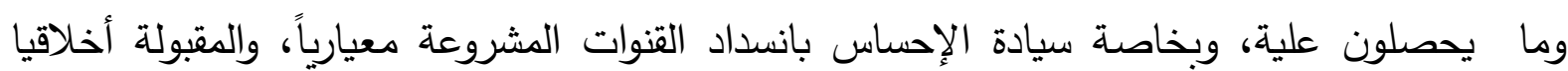

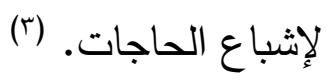

ا- العياشي عنصر : العولمة والتطرف ، نحو استكثاف علاقة ملتبسة، مجلة سياسات عربية المركز العببي للأبحاث ودراسة السياسات ،المجلد

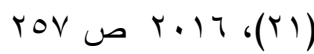

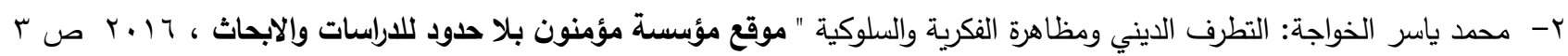

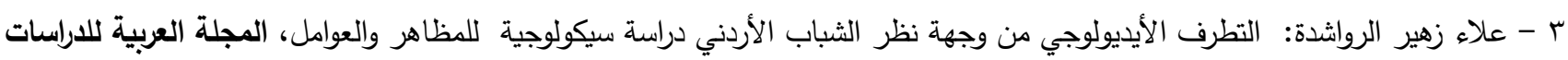

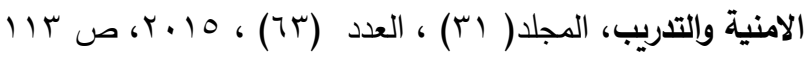




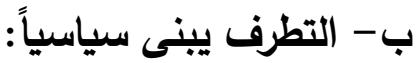

تتجسد هذه الفكرة في مستويين: الأول: بتوظيف السياسيين الظروف الصعبة السائدة بغية تحفيز

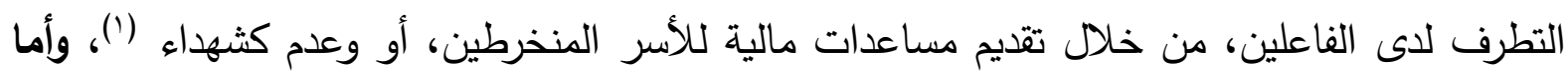
الثاني: فيظهر في شرعنه نضال الحركة، بغية لفت الانتباه إليها وتعزيز مكانتها وتأكيد قوتها.

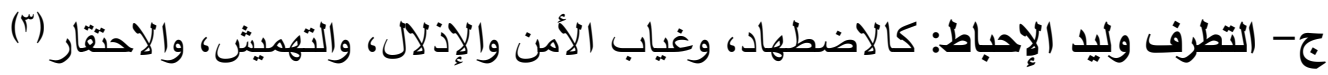

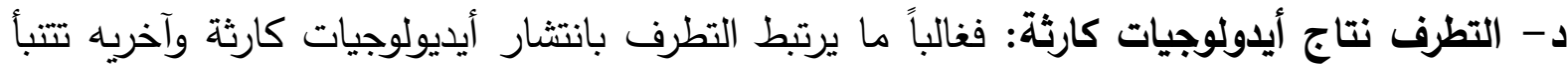

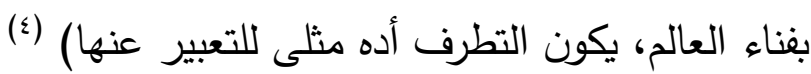
هـ - التطرف ظاهرة مرضية: ينظر إلى التطرف كونه مرضًا وطريقة في الحياة ، عندما يلجأ الافراد إلى لـى لتصن العنف لتوفير الثعورية بالحيوية ويقول غروين إن غياب الهوية المرتبط بالتطرف ناتج من هدم الذات بسبب سيطرة شعور بكراهيتها، وهو ما يؤدى بدورة إلى سيطرة شعور الثأر من الفرد علي نفسه، وشعورة

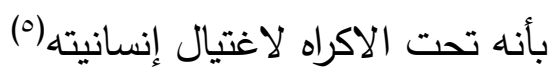

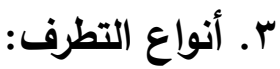

تتعد أنواع التطرف فيمكن حصرها على النحو التالي (†).

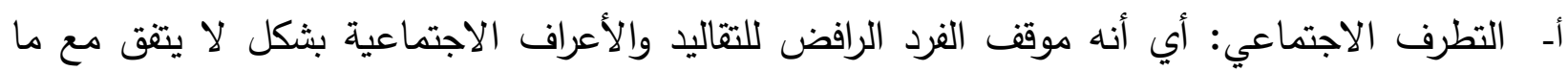

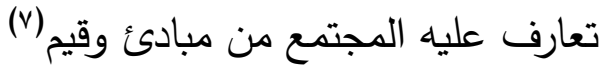

بـ التطرف الاقتصادي: والمقصود بذلك الإقبال على الاستهلاك حتى أصبح شعار الإنسان المعاصر ( أنا استهلك إذن أنا موجود ) وصارت قيمة الإنسان بما يستهلكه لا بما ينتجه.

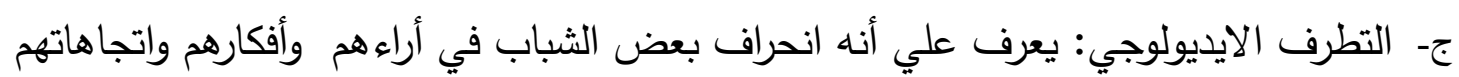

1 - إسماعيل صديق إسماعيل: التطرف والتعصب الديني أسبابه والعوامل المؤدية إليه، المجلة الليبية العالمية، كلية التربية بالمرج، جامعة بني

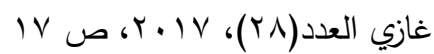

2- Bernd Simon \& Bert Klandermans "Politicized Collective Identity American Psychologist, vol. 56, no. 4 (2001), pp. $319-331$.

3- Clark McCauley, "The Psychology of Group Identification and the Power of Ethnic Nationalism", In Daniel Chicot \& Martin E. P. Seligman (Eds.) Ethno-political Warfare: Causes, Consequences, and Possible Solutions (Washington, DC: American Psychological Association, 2001), p. 350.

4- Michael Wes sells Paper Presented Peace building Matters", , "Terrorism, Apocalyptic Ideology, and Young : Martyrs Why Paper Presented at The American Psychological Association Conference, Chicago, August 2002.P154

5- Arno Green, "An Unrecognized Pathology: The Mask of Humaneness Journal of Psychohistory, vol. 30, no.3 (Win 2003), pp. $266-272$.

4- محمد قاسم المنسي: الاسلام في مواجهة التطرف، حولية مركز البحوث والدراسات الاسلامية، كلية دار العلوم جامعة القاهرة المجلد (V )،

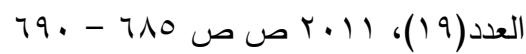

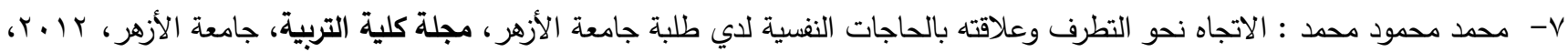


دـ التطرف في إصدار الأحكام: فهم يرون الأمور من زاوية، فالدنيا عندهم إما سواداً في سواد أو بياضاً في بياض، فلا وسط ولا مجال للتنازل أو المرونة.

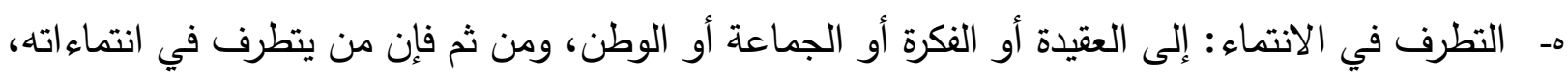

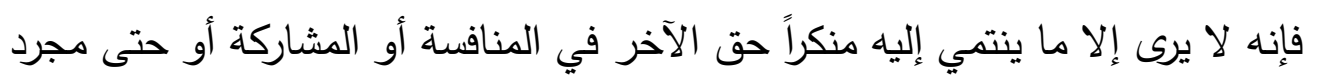

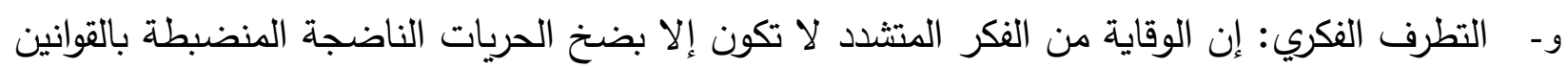

والقيم) (1) ز- التطرف في التدين: والمقصود بذلك أن يبالغ الإنسان في القيام ببعض الواجبات دون بعضها الآخر وأن

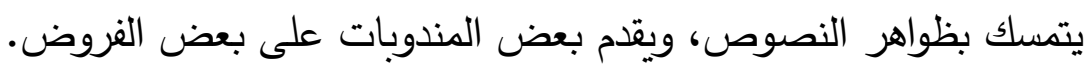

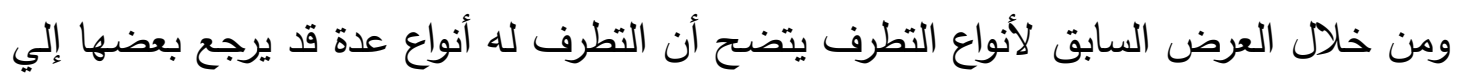
التنشئة الاجتماعية المتمثلة في الأسرة من حيث المستوي التعليمي والدخل المعيشي وكذلك البيئة الخارجية المتمثلة في الرفقاء والمدرسة ووسائل الإعلام وكذلك طبيعة الفكر المتكون بسبب التئي المؤثرات

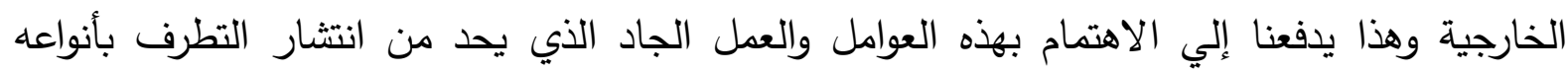
المختلفة وخاصة مرحلة التعليم قبل الجامعي ونجعلها متسقه مع أهداف التعليم وكذلك مراجعة مناهج لهناه التعليم.

؛ . مستويات التطرف: هناك أربع مستويات للتطرف وهي (†): أــ المستوى العقلي أو المعرفي والمتمثل في انعدام القدرة على التأمل والتقكير. بـ المستوى الوجداني المتمثل في بالاندفاعية في السلوك.

ج- المستوى السلوكي والمتمثل في ممارسة العنف ضد الآخرين (r) دـ المستوي النفسي والمتمثل في الاضطراب والاستيلاء علي حقوق الآخرين.

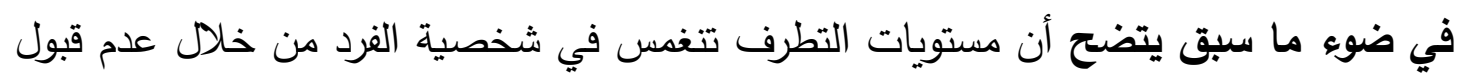

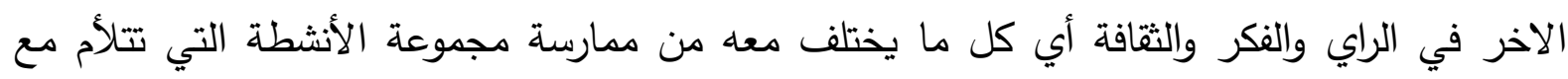
مقتضيات المعيثة فهذا يظهر له على محدودية فكرة على ما يسمى ضدنا وبالتالي ليس معنا. هـ مظاهر التطرف: وتكمن مظاهر التطرف في النقاط التالية: أ- ظاهرة تكفير المسلمين والحكم عليهم بالخروج عن دائرة الإسلام مما جعلهم يسقطون عصمة الآخرين

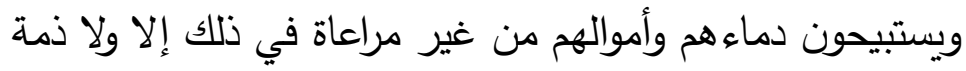

ا- بدر محمد ملك، لطيفة حسين الكندي: دور المعلم في وقاية الناشئة من التطرف الفكري، مجلة كلية التربية، جامعة الازهر، المجلد(()،

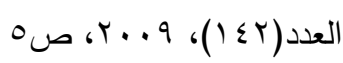

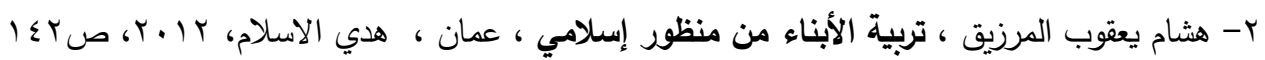

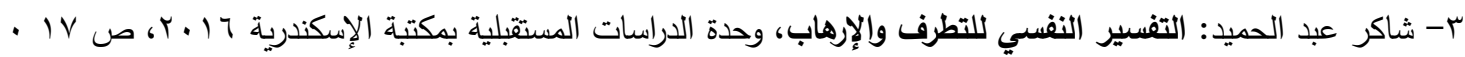


بـ التزام التشدد في الدين والتصلب فيه عن جهلٍ وجمودٍ من غير مراعاة للمكان والزمان والأحوال، كأن يكون

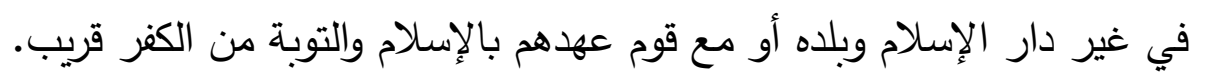

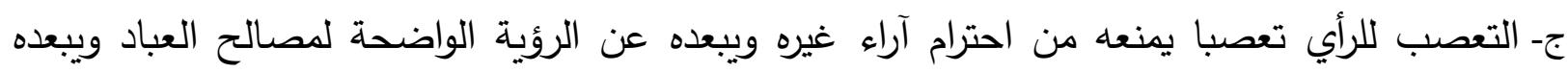

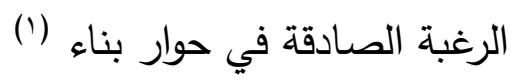
د- من مظاهر التطرف العزلة ومقاطعه الناس بناء على استثعار المتطرف بأن المجتمع الذي يعيش فيه

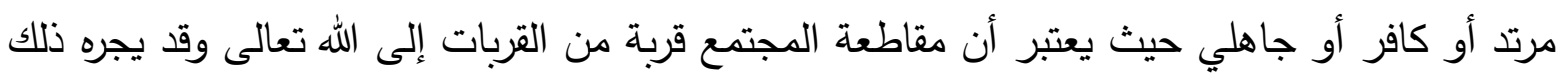

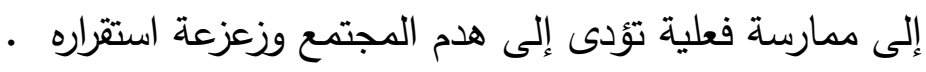

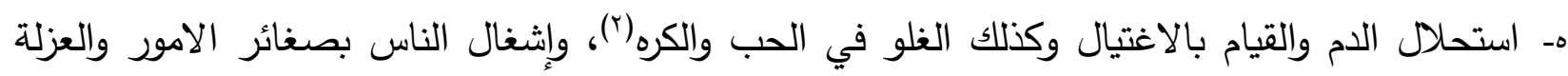

ومقاطعة الناس(). و - الغلو في الحب والكره، والطاعة العمياء، وتحجر العقول بعدم قبول الاخر.

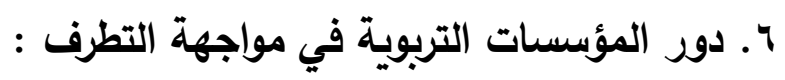
تلعب المؤسسات التربوية دور عظيم في تربية النشء واكسابهم المهارات والعادات والسلوكيات التي فولي يرتضيها المجتمع ومن أهم تلك المؤسسات: أ- الاسرة : تعد الأسرة أول مصدر لتكوين خبرات الفرد في الحياة وأهم المصادر الضبط المباشر وغير

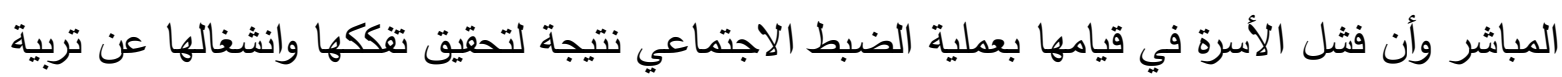

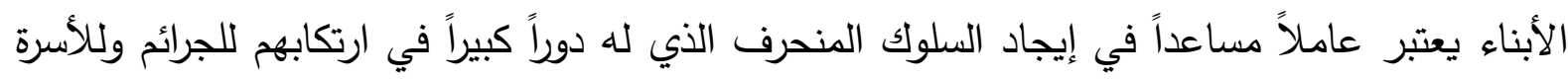

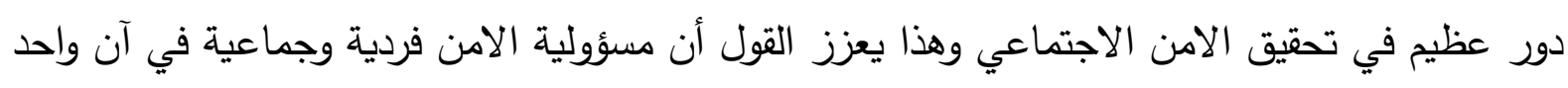

فالأسرة لها دور عظيم في تحصين أبنائها ضد التطرف والإرهاب وتعزيز الانتماء الوطني لديهم (o) ب- المدرسة : فهي تتحمل مسؤولية تتشئة الفرد وضبط سلوكه حيث تقوم بوظائف عديدة أهمها استيعاب القيم والتقاليد والأعراف الاجتماعية وغرسها في الناشئة وإنثا نماذج اجتماعية جديدة وتطوير

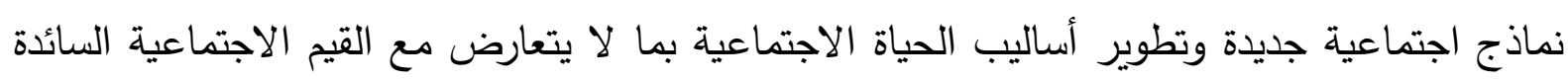
والتطوير والإبداع في الفكر والسلوك الفردي والاجتماعي لضمان مواكبة التطور والتغير ففي مجال

1- أحمد محمد زين خضر : ظاهرة التطرف وأثرها في الدعوة إلى الله، مجلة معالم الدعوة الاسلامية، كلية الدعوة الاسلامية بجامعة أم

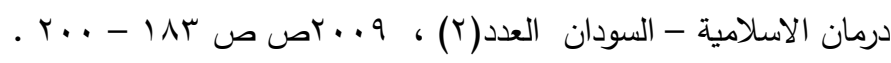

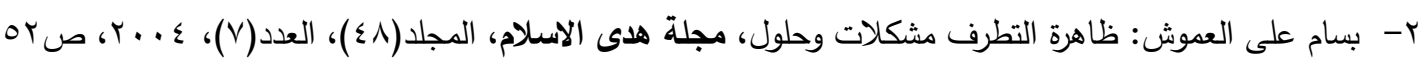

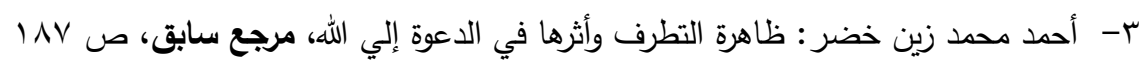

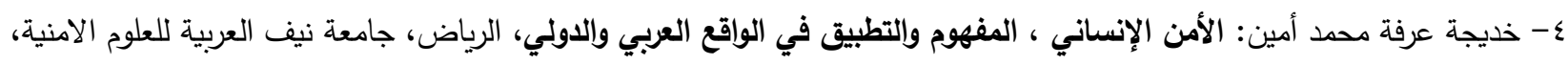

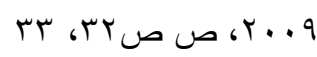
ه- رجاء الدطيري : دور الاسرة في تحصين أبنائها ضد التطرف والارهاب وتعزيز الانتماء الوطني لديهم، مركز البحوث والدراسات الإسلامية

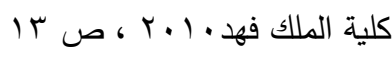


مقاومة التطرف تستطيع المؤسسة التربوية دفع الفرد للتعلم الذاتي الصحيح وحل ما قد يواجه من مشكلات وحثه على الإبداع والابتكار والتنكير المنطقي وفق القيم الاجتماعية السائدة ونبذ العنف

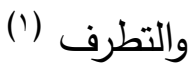

ج- المسجد: يعتبر المسجد من أهم المؤسسات الاجتماعية التربوية باعتبارها مركزاً لنشر الوعي في

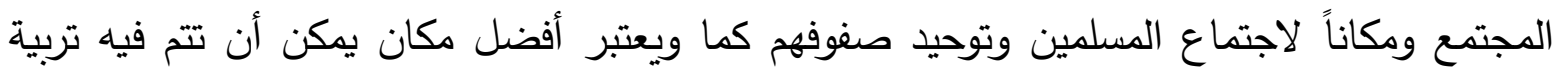

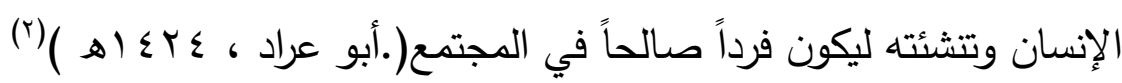
V. العوامل المؤدية للتطرف: تتعدد العوامل المؤدية للتطرف ومنها:

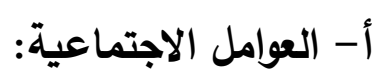

ظهور التناقض في حياة الناس(")، وتفكك المجتمع وعدم ترابطه (\&) . الفراغ فإن الفراغ مفسدة للمره وداء مهلك ومتلف للدين والنفس ـ يقول الرسول صلى الله عليه وسلم:

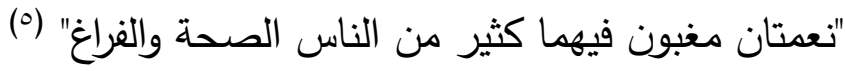
التقدم التتني وتغير المفاهيم الاجتماعية المرتبطة بوسائل التواصل الاجتماعي وهذا يؤدي بدورة إلي

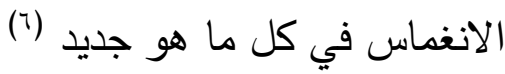

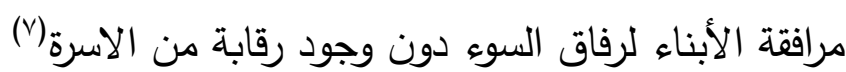
الانحراف الفكري في العلم الشرعي وذلك إما بسبب تلمذة مجموعة من الغلاة على يد من لا علم له، أو أو

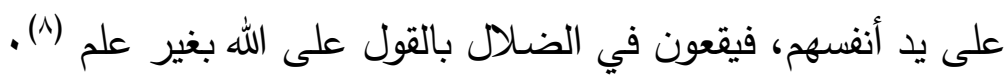
أوقات الفراغ خاصة أوقات الفراغ الذي يعانيه الثباب وهذا يؤكد الحاجة إلى توفير أندية طلابية ومراكز

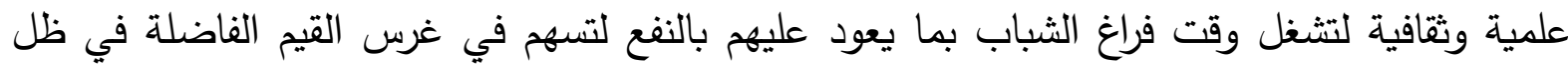
عناية وإشراف ومتابعه (9) .

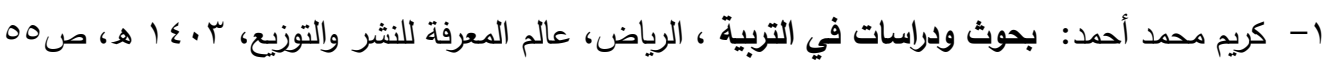

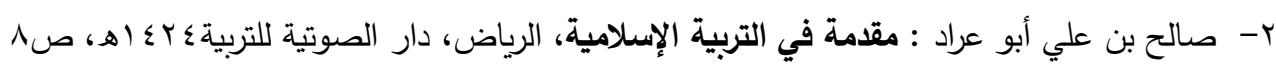

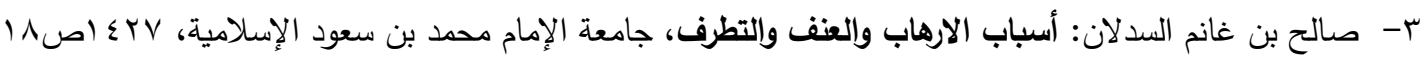

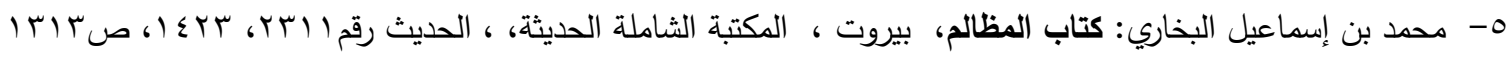

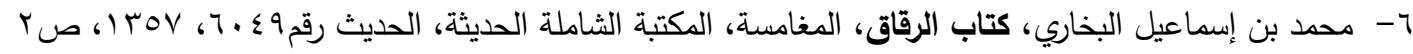

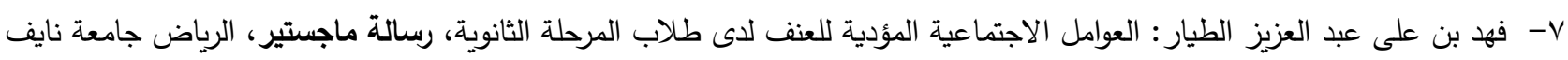

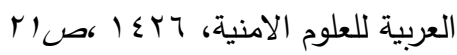
^- عاصم محمد عبد القادر : العوامل المؤدية إلى التطرف في الاسرة وسبل تحصين الابناء منها ، مجلة الجامعة الاسلامية للبحوث الاسلامية،

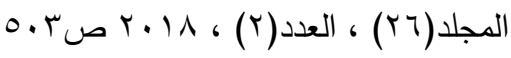
^- ناصر عبد الكريم العقل: الخوارج أول الفرق في تاريخ الإسلام، مناهجهم وأصولهم وسماتهم قديماً وحديثاً وموقف السلف منهم ، المملكة

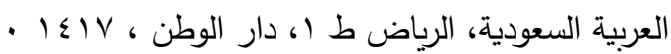

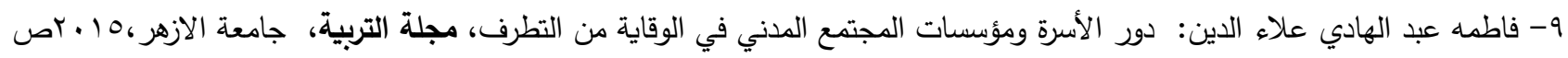


• أساليب التتشئة الاجتماعية الخاطئة، سوء التدليل أو القسوة الزائدة من قبل الوالدين وهذا يؤدي بدوره إلي تبي فكر يخالف تلك الأساليب.

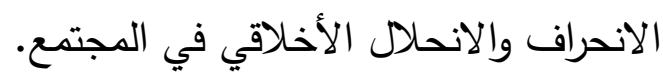

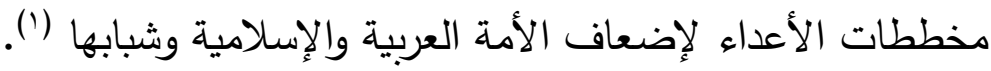
ضعف تأثير القيم الاينية والإنسانية داخل بض الأسر . لاضئ.

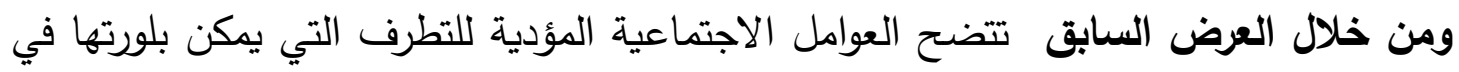
دور الاسرة لأنها تمثل الوسيط الاول والأساسي في تربية أبنائها المتمثلة في الاب والام المام وعلاقتهم بالأبناء

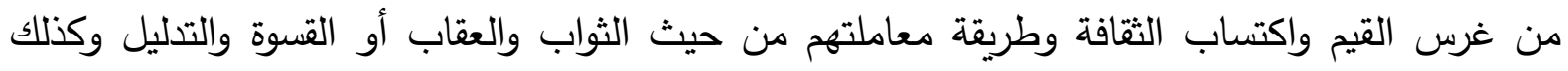
دورهم الكبير في متابعة الابناء ورفقائهم • عندين

ب- ب العوامل الاقتصادية ومنها: ويمكن ابراز العوامل الاقتصادية فيما يلي:

الفقر والبطالة من أهم أسباب اختيار طريق العن والإرهاب حيث يصبح الفرد غير قادر الإد على إثباع

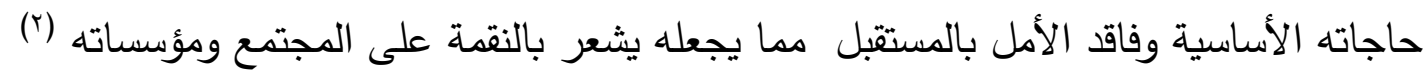
عدم أخذ الحقوق يولد سخطاً عاماً. الفساد الاقتصادي وسوء استعمال المال العام والتصرف فيه سواء أكان ذلك من قبل الحكام أو القائمين

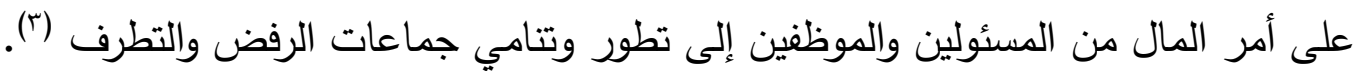
اختلاف المستويات الاقتصادية بين الطلاب.

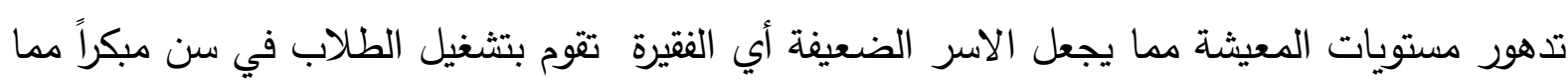
يحرمهم من فرص التعليم ويعرضهم للانحراف (\&).

عدم القدرة على إثباع الحاجات الاساسية وحدوث ما يسمى بالنزيف الطبقي (0) الرخاء الاقتصادي يؤدى إلى مستويات وطموح وأمال عريضة تفوق إمكانية المجتمع لتحقيقها، فينتج

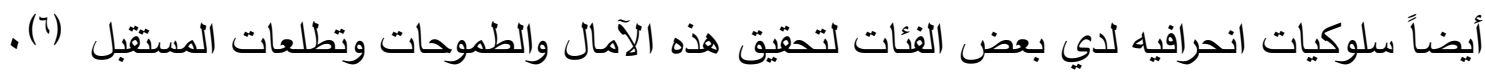
شيوع الفساد في المؤسسات وكذلك الحرمان المادي. كثرة أزمات الكساد الاقتصادي. التطلع إلي مستوي يفوق الامكانيات المادية والنكرية.

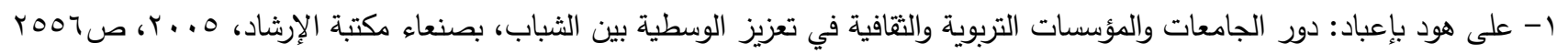

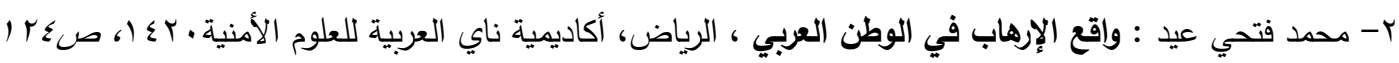

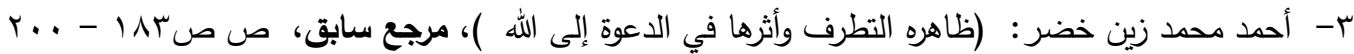

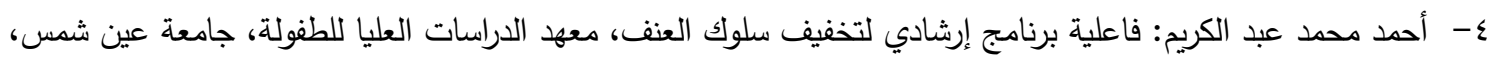

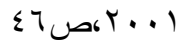

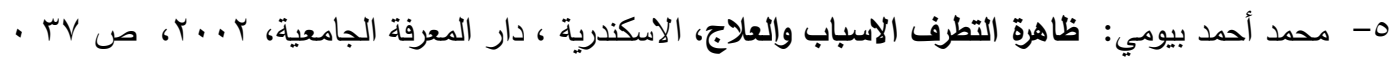

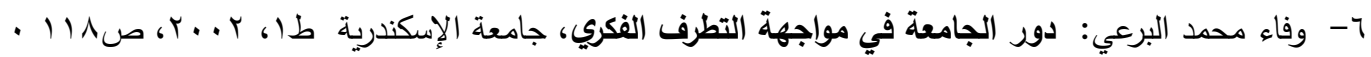


غياب تكافؤ الفرص بين الأفراد('). ومن خلال العرض السابق تتبلور العوامل الاقتصادية التي تتدفع الكثير من الثباب إلي التطرف في

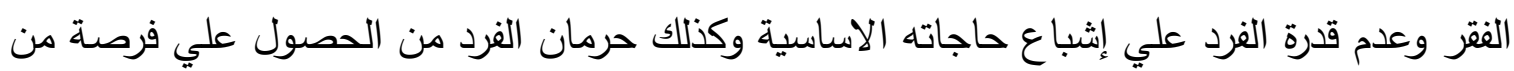

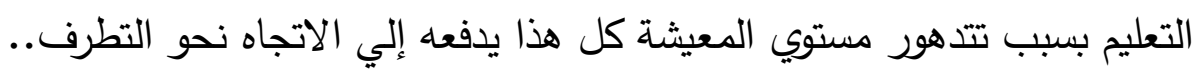

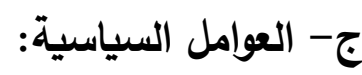

تتعد العوامل السياسية التي تدفع الثباب الى التطرف ومنها: (؟) الاضطهاد السياسي وفقدان الثقة بالعلماء واللجوء إلى أصحاب الفكر التكفيري عدم وجود عدالة سياسية، ومناخ يتسم بالحرية، والتسلط وأعمال العنف ضد الثباب(؟) نشر الثائعات من قبل بعض المؤسسات. ضعف المشاركة في العمل السياسي يدفع الثباب الى التطرف الفكري. وقصور في اهتمامات السياسيين بحقوق المواطنين، والاغتراب السياسي يدفع الثباب إلى التطرف، وتعارض سياسات الدول الخارجية مع المواطنين.

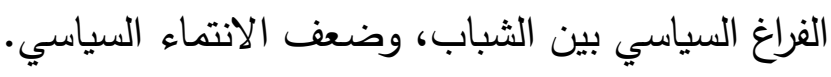

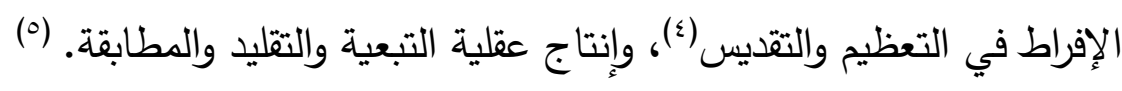
الخلاصة : الإطفي

من خلال ما تم طرحة يجب النظر بعين الاهتمام إلي مشكلة التطرف علي كونها مشكلة غير مرتبطة

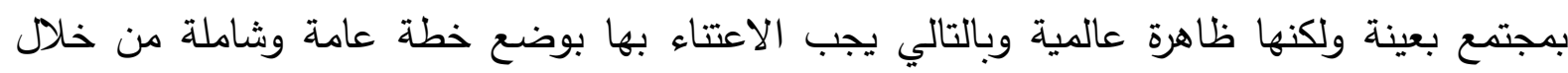

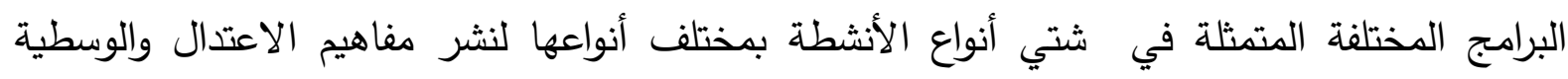

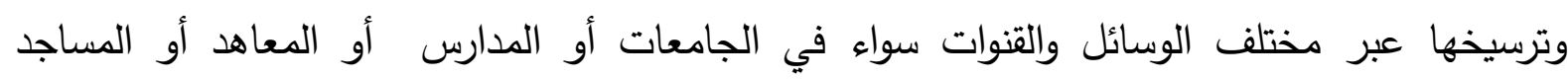
وبتضافر جهود تلك المؤسسات كلاً بدوره نستطيع الحد من تلك المشكلة.

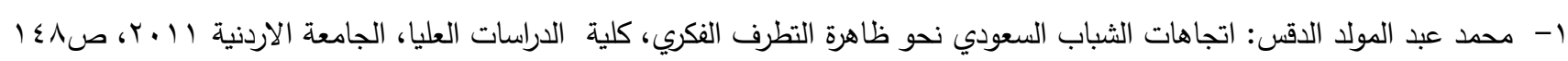
ب- أحمد القواسمة، عبد الثافي أحمد: العوامل التربوية غير السليمة المؤدية إلى انتثار ظاهرة الفكر التكفيري لاي الثباب، جامعة الملك فيصل، rTVO r- قيس سالم مجلي: دور المناهج في تتمية فكر طلاب كلية الثريعة بالجامعة الأردنية لككافحة التطرف، مجلة التربية جامعة الأزهر ،

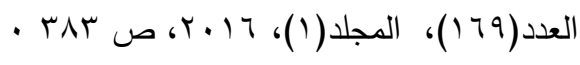
ع- قدور أحمد الثامر : مظاهر الغلو والتطرف عند بعض الفرق الإسلامية، مجلة الفنون والأدب وعلوم الإنسانيات والاجتماع، كلية الامارت

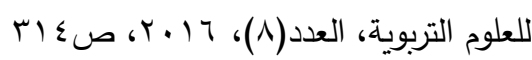

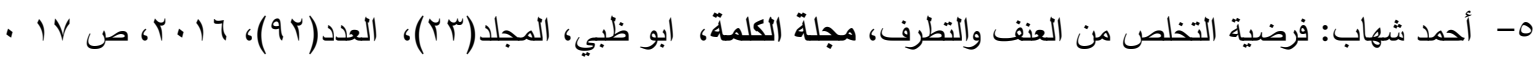




\section{إجراءات البحث الميدانية:}

للإجابة عن التساؤل الثالث ما واقع معوقات الانثطة الطلابية بالمعاهد الأزهرية بالوادي الجديد يكمن الهدف الرئيسي للبحث الحالي في التعرف على معوقات الانشطة الطلابية في المعاهد الأزهرية بمحافظة الوادي الجديد ؛ لذا يتم يتناول إجراءات البحث الميدانية للوقوف علي المعوقات التي تحول

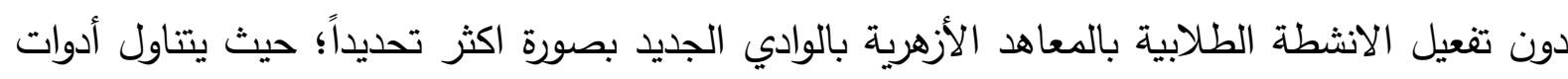
الدراسة واجراءات تقنينها، مجموعة الدراسة وإجراءات اختيارها، والمعالجة الاحصائية المستخدمة في بالي تفسير النتائج.

أولا : أدوات البحث واجراءات تقنينها: نظرًا لأن طلاب المعاهد الثانوية الأزهرية هم الممارسين للأنثطة الطلابية، ومن ثمّ فهم قادرون على إظهار الواقع الفعلي للأنثطة الطلابية؛ لذا فقد استخدم الباحث الاستبانة باعتبارها من الأساليب

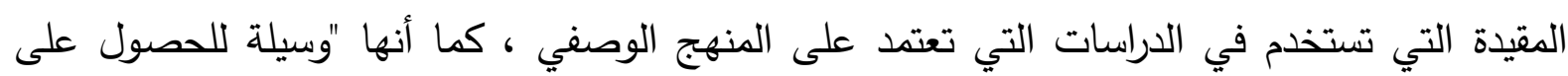
اجابات مكتوبة بعدد معين من الأسئلة الموضوعية للكثف عن آراء الفئة التي يدور حولها البحث واتجاهاتهم نحو الموضوعات التي يتضمنها , كما أنها تستخدم للتعرف على آراء المبحثين من عينة

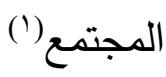
ولتحقيق اهداف البحث قام الباحث ببناء استبانة لمعرفة واقع معوقات الانشطة الطلابية في

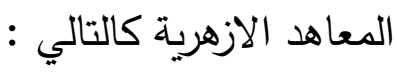
ا. مرحلة الاعداد : اعداد الصورة الاولية للاستبانة هذه الاستبانة مرت بعدة مراحل حتي وصلت الي صورتها النهائية و يمكن ايجازها فيما يلي :أ - من خلال تحليل للمعلومات التي حصل عليها من المصادر و المراجع العربية و الاجنبية المتصلة بالأنشطة الطلابية، وواقع عمل الباحث كمعلم قرآن كريم في المعاهد الازهرية بالوادي الجديد ومن خلا آراء بعض الخبراء في مجال الانثطة الطلابية بالمعاهد تم تجميع العديد من العبارات التي توضح

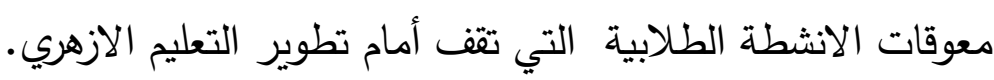

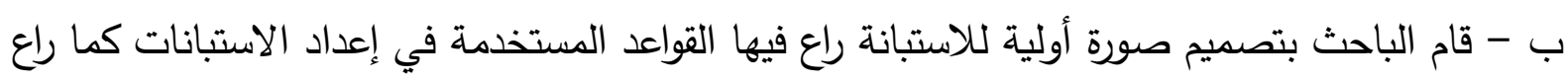
ان يختتم كل بعد بسؤال مفتوح لإعطاء المستجيب حرية للإجابة و للحصول علي الآراء التي قد تكون

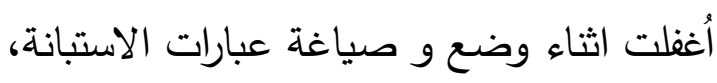

(') على معمر عبد المؤمن: مناهج البحث في العلوم الاجتماعية" الأساسيات والتقنيات والأساليب، الإدارة العامة للمكتبات، القاهرة،

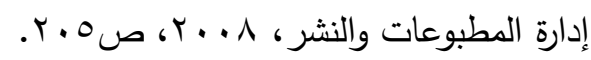


د- تكونت الاستبانة في صورتها الاولية من جزئيين :

الجزء الاول : بيانات شخصية

الجزء الثاني معوقات الانشطة الطلابية بالمعاهد الأزهرية بالوادي الجديد.

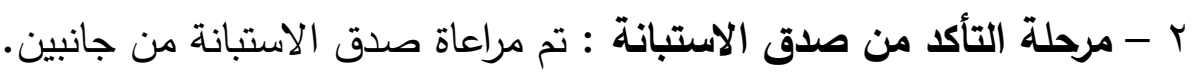

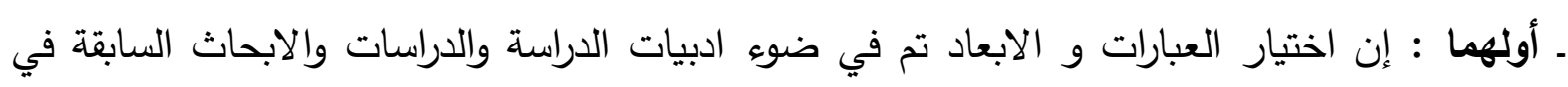

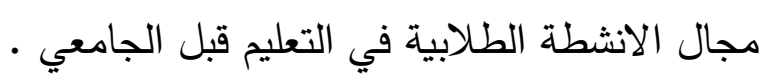
ـ ثانيهما : الصدق : فقد تم عرض الاستبانة علي مجموعة المحكمين من الخبراء وأعضاء هيئة التدريس في لهاء بالجامعات المختلفة، وقد قاموا مشكورين بإبداء بعض الملاحظات من حذف و تعديل بعض العبارات و التي وضعها الباحث في الاعتبار وأصبح عدد العبارات سا أعبارة.

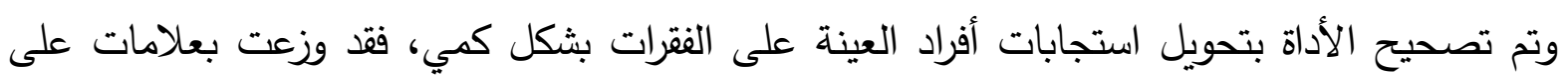
التدريج الثلاثي:-

- فأعطيت العبارات الموجبة درجة (يتحقق) بثلاث علامات، (يتحقق إلي حد ما) بعلامتين. ودرجة (لاتئ يتحقق) بعلامة واحدة.

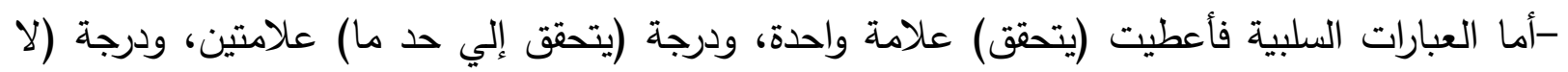
يتحقق) ثلاث علامات. ثانياً: عينة البحث وإجراء ات اختيارها:يوجد بمحافظة الوادي الجديد بrمعهداً أزهرياً منها (T) معاهد أزهرية بمنطقة الوادي الجديد بمدينة الخارجة ويوجد (r ) معهد أزهري بمنطقة الداخلة، وباختيار معاهد الداخلة والخارجة وصل عدد المعاهد إلي ^^امعهدً أزهرياً ولقد قام الباحث باختيار العينة من المعاهد بطريقة عشوائية من خلال اختيار الطلاب من القوائم بتطبيق، وبلغ عدد العينة (• (r) طالب وطالبة، وتم تطبيق أداة الدراسة عليهم. ('). 
ويوضح جدول ( () المعاهد الأزهرية في مناطق الخارجة، والداخلة، التي تم التطبيق عليها.

جدول رقم (1) (1) (1) (1)

موصفات العينة ونسبتها إلي المجتمع الأصلي تعديل هذا الجدول

\begin{tabular}{|c|c|c|c|c|c|}
\hline 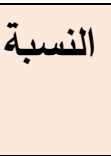 & 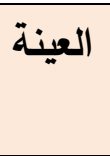 & الاصلي & أسماء المعاهد الأزهرية & 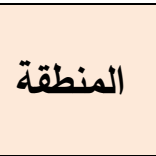 & p \\
\hline$\%$ \%r & $r$. & IrA & 1- معهد فتيات الخارجة الإعدادي الثانوي. & منطقة & 1 \\
\hline$\% 17$ & r. & 119 & r- معهد ناصر بنين الإعدادي الثانوي. & الخارجة & \\
\hline$\%$ & $1 \cdot$ & $r \cdot$ & r- معهد فتيات باريس الإعدادي الثانوي. & الأزهرية & \\
\hline$\%$ \% & $\wedge$ & r) & ـ - معهد باريس الإعدادي الثانوي بنين. & & \\
\hline$\% \varepsilon r$ & ir & $r \cdot$ & 0- معهد جو رمشين V الثانوي بنين. & & \\
\hline$\% .00$ & 1. & 1 & 7- معهد جو رمشين V الثانوي فتيات. & & \\
\hline$\%$ ro & rq & 114 & 1- معهد فتتات موط الإعدادي الثانوي & الداخلة & $-r$ \\
\hline$\%$ iv & r. & $11 \mathrm{~V}$ & 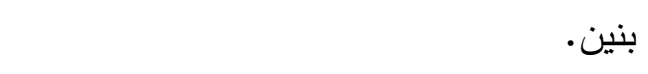 & & \\
\hline$\%$ & $\wedge$ & ry & r- معهد بنين موط الإعدادي الثانوي & & \\
\hline$\%$ & 9 & 11 & فتيات & & \\
\hline \% & ○ & 10 & r- المعصرة الثانوي بنين & & \\
\hline$\% \varepsilon \varepsilon$ & $\wedge$ & 11 & ع- المعصرة الثانوي فتيات & & \\
\hline$\% \varepsilon$ & 7 & 10 & 0- عزب القصر الثانوي بنين & & \\
\hline$\%$ & $\wedge$ & 17 & ז- عزب القصر الثانوي فتيات & & \\
\hline$\%$ r & $v$ & ry & V- الجديدة الثانوي بنين. & & \\
\hline$\%$ & $\varepsilon$ & $\wedge$ & 1- الجديدة الثانوي فتيات & & \\
\hline$\%(r$ & 9 & $\varepsilon r$ & 9- غرب الموهوب الثانوي بنين & & \\
\hline$\%$ ro & 7 & r & 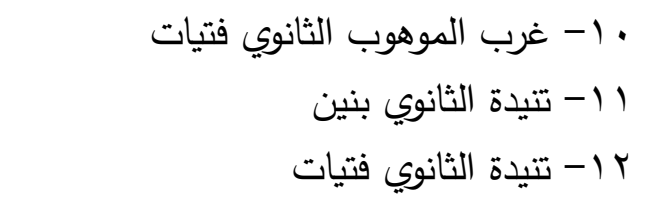 & & \\
\hline$\%$ \% & 119 & $\varepsilon \leqslant \leqslant$ & 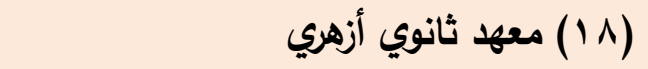 & & الإجد \\
\hline
\end{tabular}

ومن خلال الجدول السابق يتضح أن نسبة العينة تراوحت بين 17 \% كدد أدنى بمعهد ناصر بنين

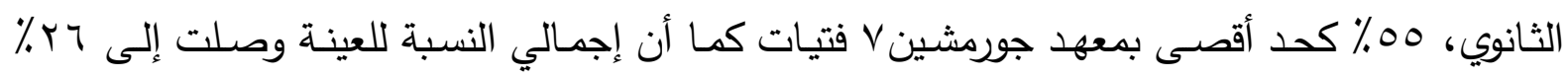
وهذه النسبة كافية لتمثيل مجتمع الدراسة.

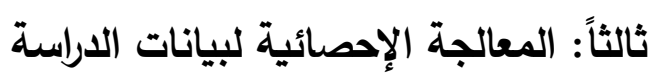
- - المعالجات الاحصائية المستخدمة: تم تفريغ وتحليل الاستبانة بواسطة البرنامج الاحصائي (SPSS 26 ) وتم استخدام الاختبارات الاحصائية الآتية: 


\section{-}

- بزيادة إيضاح العلامات التي حصل عليها أفراد عينة الدراسة ثم استخراج النسب المئوية التي تبين العلامات بصورة سهلة تساعد في تحديد الفرق بين المتوسطات المتقاربة في الدرجات، واستخدمت كذلك

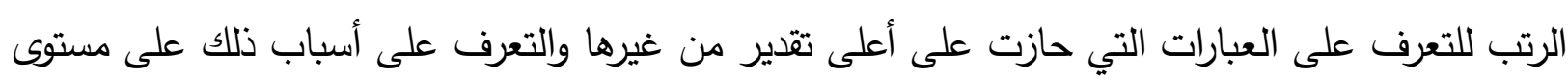
الأبعاد.

- - اختبار الفا كرو نباخ للتأكد من ثبات الاستبانة. - - معامل ارتباط بيرسون لحساب التناسق الداخلي. - - المتوسط المرجح والانحرافات المعيارية.

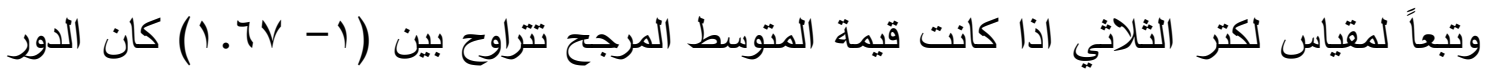

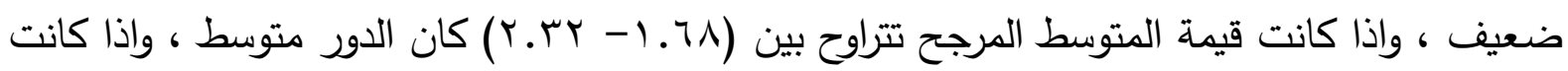

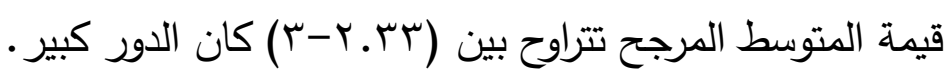




\section{نتائج البحث وتفسيرها}

وسوف يتم تتاول النتائج وتقسيرها على النحو التالي:

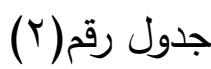

المتوسط المرجح والاتجاه لاستجابات أفراد العينة حول معوقات النثاط الطلابي في المعاهد الأزهرية

\begin{tabular}{|c|c|c|c|c|c|}
\hline 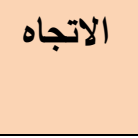 & الترتيب & 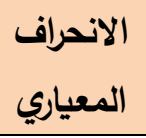 & المتوسط & العبــــــارة & P \\
\hline كبيرة & $\varepsilon$ &.$v 14$ & r.OV & الأثثطة المقمة لا تتاسب ميول وقرات الطلاب & 1 \\
\hline متوسطة & 11 & $.00 \mathrm{~V}$ & r... & الأزهرية الإمكانات المانية المخصصة لممارسة الأثثطة في المعاهد & r \\
\hline متوسطة & 1. & rra & r... & وعي الطلاب بالأثثطة المقدمة داخل المعاهد الأزهرية ضعيف & $r$ \\
\hline متوسطة & $\wedge$ & .001 & r..r & | داخل المعد المثرفين المتخصصين في ممارسة أنثطة طلابية متوعة & $\varepsilon$ \\
\hline كبيرة & 1 & . & r.Ar & | ضعف وضوح الفلسفة التي تصمم في ضوئها خطة الأنشطة & 。 \\
\hline متوسطة & 7 & . & $r . . v$ & | قلة الحصص المخصصة لممارسة الأثثطة & 1 \\
\hline متوسطة & ir & 单 & $1.9 \mathrm{~V}$ & القواعد المحدة للانضمام للنشاط الطلابي غير واضحة & 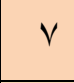 \\
\hline متوسطة & ir & .079 & 1.94 & قلة الأماكن في المعاهد الأزهرية لمعارسة النثاط (مسرح- ملعب). & $\wedge$ \\
\hline كبيرة & $r$ & $.0 \mathrm{~V}$. & r.V $\leqslant$ & 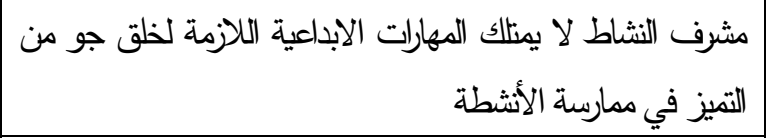 & 9 \\
\hline متوسطة & $v$ & . & r... $\varepsilon$ & كثرة الاجراءات الروتينية اللازمة لممارسة النشاط & 1. \\
\hline كبيرة & o & . & $r . r \varepsilon$ & |لدراسلة التزام المعاهد الأزهرية بخطة الأنثطة وتتفيذها طوال العام & 11 \\
\hline متوسطة & 9 & . & r... & | لا يشهم بأهيتها أولياء الأهور أبناءهم علي ممارسة الأثشطة لقلة وجود & ir \\
\hline كبيرة & r & .0 .1 & r.V^ & قلة الحوافز المانية المقدمة المعلمين لتثجيعهم علي ممارسة النثاط & ir \\
\hline كبيرة & & $.0 . \xi$ & T.ru & 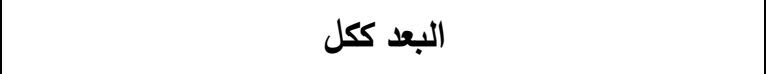 & \\
\hline
\end{tabular}

يتضح من الجدول رقم (Y) أن أفراد العينة متفقون على وجود معوقات تواجه الانشطة الطلابية في

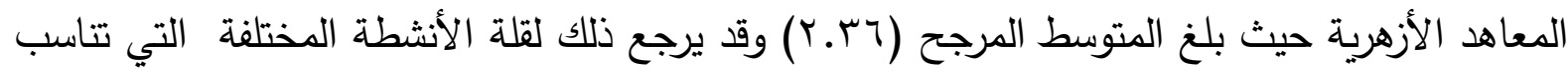

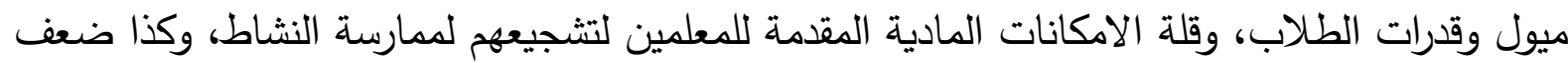
وضوح الفلسفة التي تصمم في ضوئها خطة الأنشطة، وقلة التزام المعاهد الأزهرية بخطة الأنشطة وتتفيذها طوال العام الدراسي وقلة الوعي بهذه الأنشطة. 
- - جاءت العبارة رقم (0) التي تتص علي "ضعف وضوح الفلسفة التي تصمم في ضوئها خطة الأنثطة" في المرتبة الأولي بالنسبة للعينة، وهي معوق بدرجة كبيرة، وقد يرجع ذلك إلي قلة الاهتمام بتوضيح

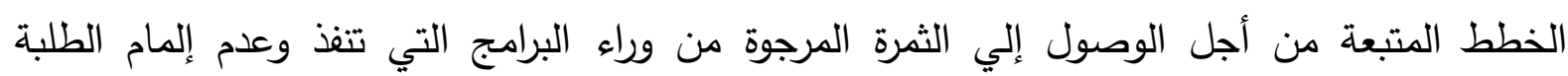

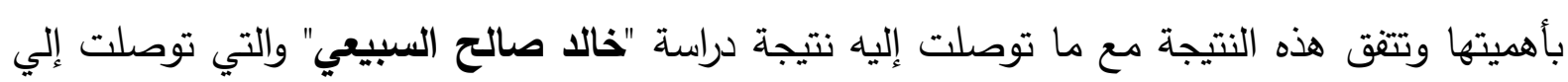
ضعف وضوح الفلسفة وقلة وضوح الخطط التي تتفذ علي أرض الواقع بسبب عدم توضيحها للطلبة. - أتت العبارة رقم( ( ) التي تتص علي “قلة الحوافز المادية المقدمة للمعلمين لتشجيعهم علي ممارسة النشاط" في المرتبة الثانية بالنسبة للعينة ككل، وهي معوق بدرجة كبيرة، وقد يرجع ذلك إلي قلة النسبة المحددة الخاصة بالحوافز المادية بسبب كثرة الاعباء المقدمة في النواحي الأخرى وتتقق هذه النتيجة مع ما توصلت إليه نتيجة الدراسة "خاد صالح السبيعي" والتي توصلت إلي قلة وجود الحوافز المادية أو المعنوية سوء المقدمة كحوافز للمعلمين أو لتنفيذ الانثطة. حصلت العبارة رقم (9) والتي تتص " مشرف النشاط لا يمتلك المهارات الابداعية اللازمة لخلق جو من التميز في ممارسة الأنثطة" علي المرتبة الثالثة بالنسبة للعينة ككل، وهي معوق بدرجة كبيرة، وقد يرجع ذلك إلي ضعف امتلاك مشرفي النشاط في اكتثاف حاجات وميول وقدرات الطلاب، وتتقق هذه النتيجة مع ما توصلت إليه نتيجة دراسة " بدر العتيبي " والتي توصلت إلي ضعف امتلاك المعلمين و مشرفي النشاط للمهارات الابداعية اللازمة لخلق مناخ من التميز والإبداع في ممارسة الأنثطة. - وجاءت بعدها العبارة رقم ( ) والتي تتص علي "الأنثطة المقدمة لا تناسب ميول وقدرات الطلاب" في المرتبة الرابعة بالنسبة للعينة ككل، وهي معوق بدرجة كبيرة، وقد يرجع ذلك إلي وضع الأنثطة بطريقة غير مدروسة بثكل كافي وتتفق هذه النتيجة مع ما توصلت إليه نتيجة الدراسة (جلال عبد الوهاب) والتي توصلت إلي عدم إعطاء الطالب الحرية في اختيار الأنشطة التي تتاسب ميوله وتثبع حاجاته وبالتالي ينبغي من خلالها إعطاء الطالب الفرصة في اختيار الأنثطة التي تتاسب ميوله. - وردت العبارة رقم (1) والتي تتص علي "قلة التزام المعاهد الأزهرية بخطة الأنثطة وتنفيذها طوال العام الدراسي" في الخامسة بالنسبة للعينة ككل، وهي معوق بدرجة كبيرة، وقد يرجع ذلك إلي كثرة الاجراءات وقلة التزام المعاهد الأزهرية بخطة الأنشطة وتتفق هذه النتيجة مع ما توصلت إليه نتيجة الدراسة (مدحت محمد أبو نصر) والتي توصلت إلي قلة تفعيل الأنشطة بسبب عدم وجود درجات للنشاط عدم إدراك الطلاب لأهمية الأنشطة ويرون أنها سوف تعطلهم عن التحصيل الدراسي. - حصلت العبارة رقم (†) والتي تصص علي "قلة الحصص المخصصة لممارسة الأنشطة" علي المرتبة السادسة بالنسبة للعينة ككل وهي معوق بدرجة متوسطة، وقد يرجع ذلك إلي كثرة المواد الدراسية المقررة 
واعتبار الانثطة ثانوية، وتتقق هذه النتيجة مع ما توصلت إليه نتيجة الدراسة (جلال عبدالوهاب) والتي توصلت إلي قلة توفر الوقت الكافي لاى الطلاب لممارسة الأنثطة الطلابية لازدحام الجداول بالمواد الدراسية وبالتالي يجب ربط الأنثطة بالمقررات الدراسية حتي تحذو حذوها. - وردت العبارة رقم (• (1) والتي تتص علي "كثرة الاجراءات الروتينية اللازمة لممارسة النشاط" في المرتبة السابعة بالنسبة للعينة ككل وهي معوق بدرجة متوسطة، وقد يرجع ذلك إلي كثرة الاجراءات التي تتخذ في تتفيذ النشاط التي منها كثرة مرور مشرف النشاط علي جهات مختلفة من أجل القيام برحلة للطلبة وهذا علي سبيل المثال لا علي سبيل الحصر وتتفق هذه النتيجة مع ما توصلت إليه نتيجة

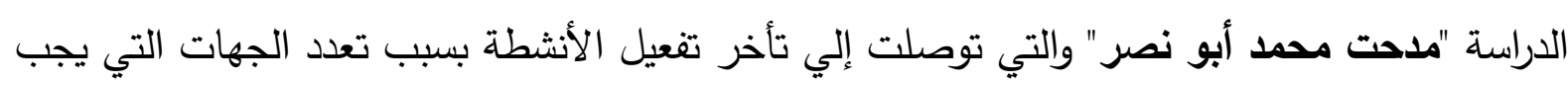
المرور بها من أجل ممارسة النشاط.

- مردت العبارة رقم (؟) والتي تتص علي "قلة عدد المشرفين المتخصصين في ممارسة أنثطة طلابية متنوعة داخل المعهد" في المرتبة الثامنة بالنسبة للعينة ككل وهي معوق بدرجة متوسطة، وقد يرجع ذلك إلي ضعف توظيف التخصصات بسبب قلة الاهتمام بممارسة النشاط لكونه لا يضاف في الغالب إلي بلي

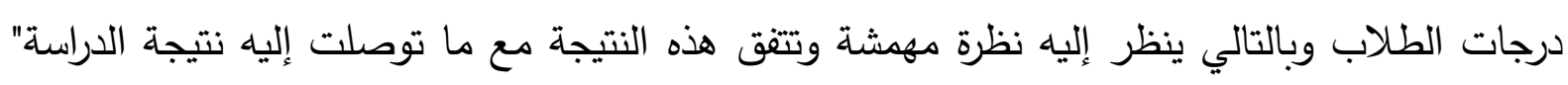
الحسين حامد محمد حسين " والتي توصلت إلي عدم وجود مختصين مؤهلين للإثراف على الأنثطة ومتابعتها. - حصلت العبارة رقم العبارة (Y I) والتي تتص علي "لا يشجع أولياء الأمور أبناءهم علي ممارسة

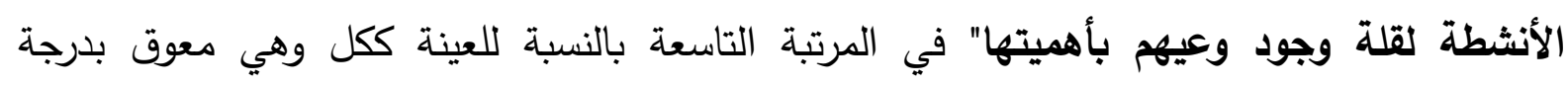
متوسطة، وقد يرجع ذلك إلي كثرة ضغط الطلبة بالمواد الدراسية الأخرى وبسبب قلة وعي أولياء الأمور

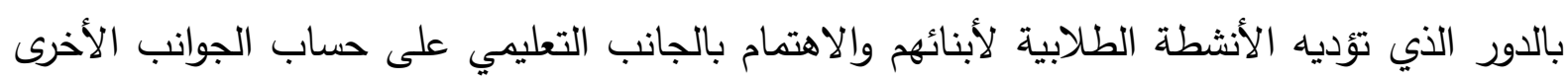

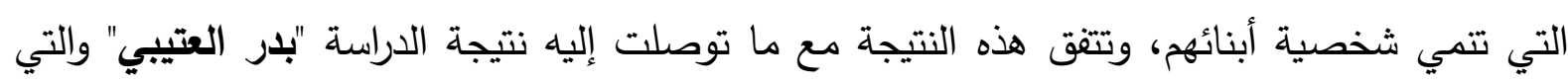
توصلت إلي ضعف وعى أسر الطلاب بأهمية الأنشطة. - جاءت العبارة رقم (؟r) والتي تتص علي "وعي الطلاب بالأنثطة المقدمة داخل المعاهد الأزهرية ضعيف" في المرتبة العاشرة بالنسبة للعينة ككل وهي معوق بدرجة متوسطة، وقد يرجع ذلك إلي كثرة

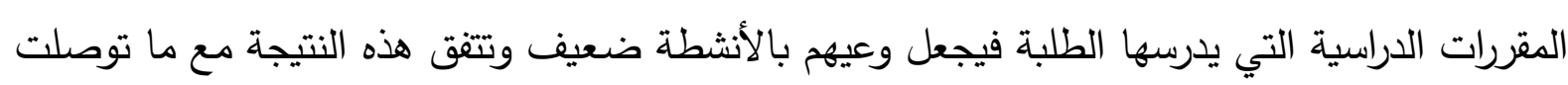
إليه نتيجة الدراسة "صالح صبري حجازي" والتي توصلت إلي قلة وعي الطلاب بأهداف النشاط، وضيق الوقت وانثغال الطلاب بالاستذكار من بداية الفصل الدراسي والعزوف عن الاشتراك في الأنثطة. 
- وردت العبارة رقم (r) والتي تتص علي “قلة الإمكانات المادية المخصصة لممارسة الأنشطة في المعاهد الأزهرية" في المرتبة الحادية عشر بالنسبة للعينة ككل، وهي معوق بدرجة متوسطة، وقد يرجع ذلك إلي كثرة متطلبات الادوات اللازمة لممارسة الأنثطة مما يتطلب أعباء مادية يجعل تفعيل النثاط طلب ثانوي وتتفق هذه النتيجة مع ما توصلت إليه نتيجة دراسة "الحسين حامد محمد" والتي توصلت إلي عدم توفر الإمكانات المادية والخامات اللازمة لممارسة الأنشطة المختلفة. - حصلت العبارة رقم العبارة (V) والتي تتص علي" القواعد المحدة للانضمام للنشاط الطلابي غير واضحة" علي المرتبة الثانية عشر بالنسبة للعينة ككل، وهي معوق بدرجة متوسطة، وقد يرجع ذلك إلي كثرة الاجراءات المتبعة للانضمام للنشاط الطلابي، وتتفق هذه النتيجة مع ما توصلت إليه نتيجة دراسة" Rider University Architects للنشاط الطلابي. - جاءت العبارة رقم (^) والتي تنص علي "قلة الاماكن في المعاهد الأزهرية لممارسة النشاط (مسرحملعب)" في المرتبة الاخيرة بالنسبة للعينة ككل؛ وهي معوق بدرجة متوسطة، وقد يرجع ذلك إلي قلة المباني والمساحات اللازمة لممارسة الأنشطة المختلفة، واستخدام الأماكن للتدريس، وتتثق هذه النتيجة مع ما توصلت إليه نتيجة دراسة "جلال عبد الوهاب" والتي توصلت إلي عدم توفر الأماكن الملائمة لممارسة النشاط. النتائج والتوصيات المقترحة: - - - اتفق افراد العينة ككل على أن هناك معوقات تحول دون تطبيق الانثطة الطلابية في المعاهد الازهرية

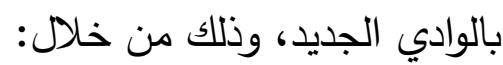
- - الأنشطة المقدمة لا تتاسب ميول وقدرات الطلاب.

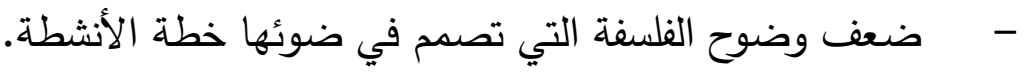
- مشرف النشاط لا يمتلك المهارات الابداعية اللازمة لخلق جو من التميز في ممارسة الأنشطة. قلة التزام المعاهد الأزهرية بخطة الأنشطة وتنفيذها طوال العام الدراسي. قلة الحوافز المادية المقدمة للمعلمين لتثجيعهم علي ممارسة النشاط. - - لا توجد قواعد واضحة محددة للانضمام للنشاط الطلابي بالمعاهد الأزهرية. - - كثرة الاجراءات الروتينية اللازمة لممارسة الأنثطة الطلابية بالمعاهد الأزهرية. - - ملة الاماكن في المعاهد الأزهرية لممارسة النشاط (مسرح- ملعب). 


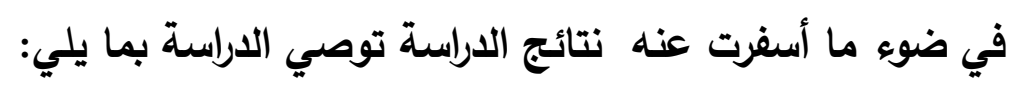
1- ضرورة تتوع الانشطة حتي يختار الطالب منها ما يناسب ميوله.

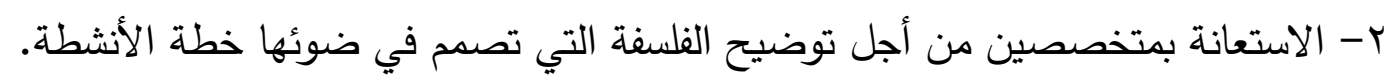

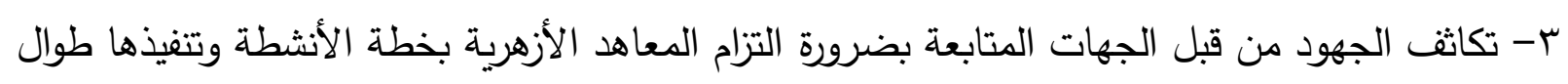
العام الدراسي. ع - عمل دورات بشكل مستمر حتي يتسنى لمشرفي النشاط أن يمتلكوا المهارات الابداعية اللازمة لخلق مناخ من التميز في ممارسة الأنشطة. 0- توفير الإمكانات المادية والبشرية الكفيلة بالنهوض بالأنشطة الطلابية في المعاهد الأزهرية . 1- العمل على تغيير النظرة السلبية للطلاب والمعلمين وأولياء الأمور تجاه الأنثطة الطلابية. V- ضرورة تنويع الأنشطة الطلابية لتناسب اهتمامات الطلاب وميولهم وقدراتهم. 


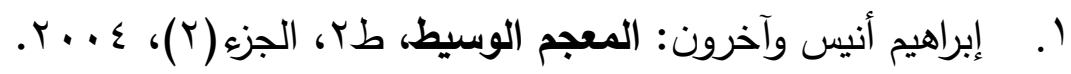

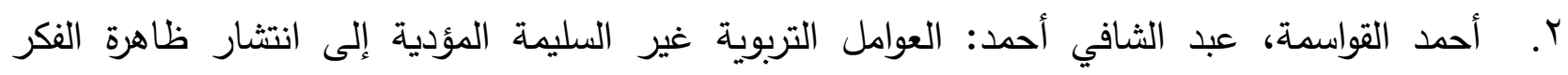

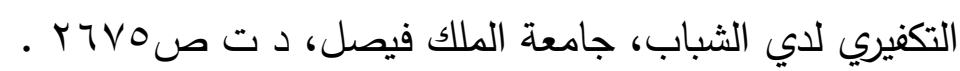

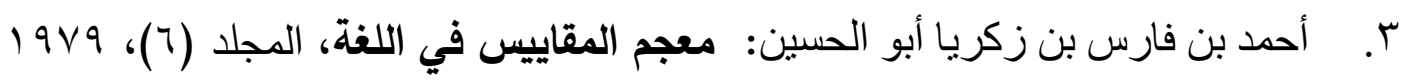

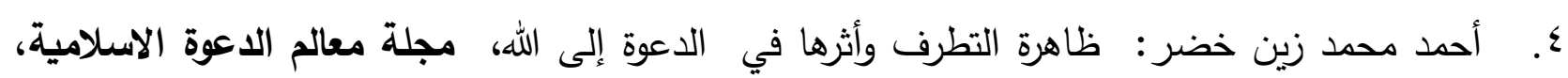

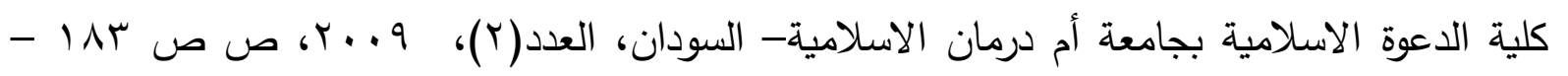
○. أحمد محمد عبد الكريم: فاعلية برنامج إرشادي لتخفيف سلوك العنف، معهذ الدراسات العليا للطفولة،

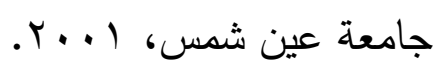
T. السعيد محمود السعيد: "الأنشطة الطلابية ودورها في العملية التربوية"، حولية كلية المعلمين في أبها،

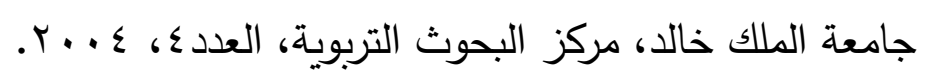

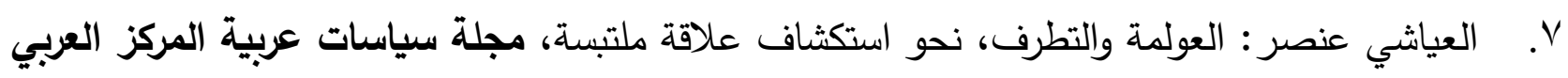

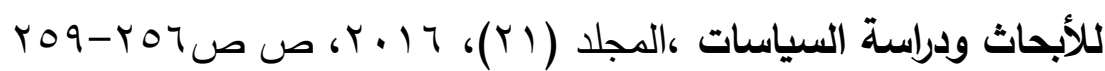

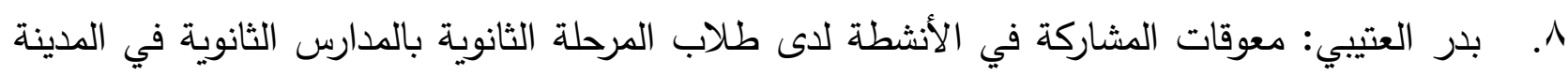

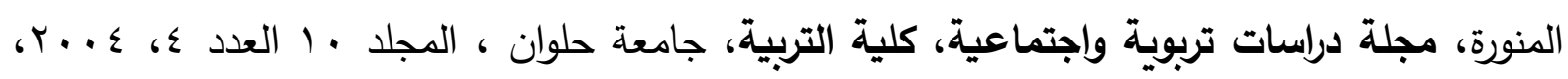

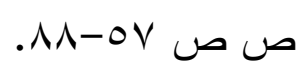

بدر محمد ملك، لطيفة حسين الكندي: دور المعلم في وقاية الناشئة من التطرف الفكري، مجلة كلية

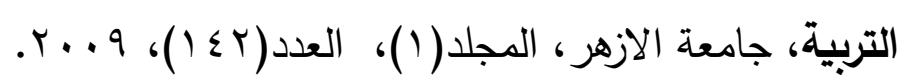

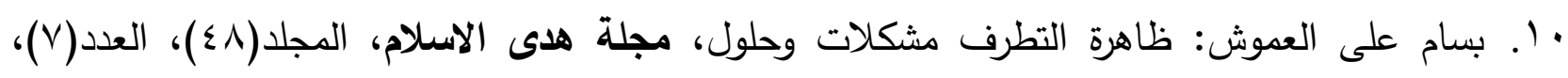
. . . E 11. توفيق قمر عصام، ورجاء محمود عثمان: النثاط الطلابي، أسس نظرية- تجارب عالمية-تطبيقات

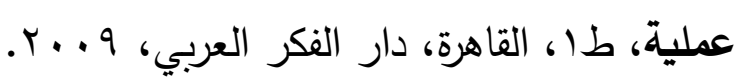

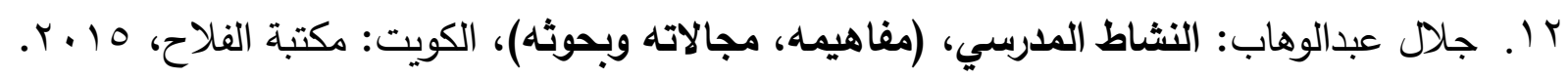

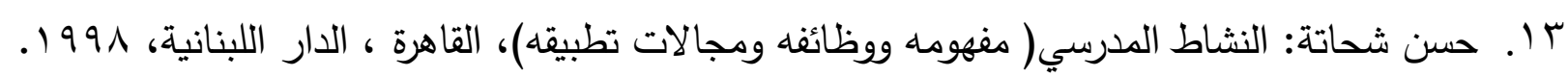
ـ ا. الحسين حادد محمد حسين: التربوية وتتمية الوعي الوطني لدي تلاميذ التعليم الاساسي، رسالة ماجستير، كلية التربية، جامعة جنوب الوادي، و . . r. 
10. حسين كامل بهاء الدين: تعزيز الثراكة مع المجتمع المحلي لخدمة التعليم للجميع, وزارة التربية والتعليم

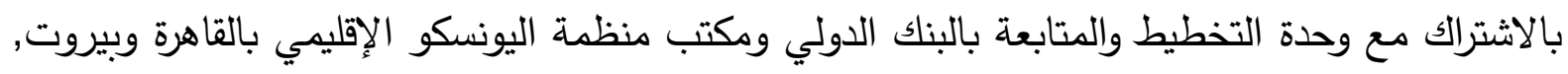
القاهرة، r. . r. 17 1. حنان ثابت مدبولي: "واقع الأنثطة الطلابية في المدارس الثانوية للبنات بمحافظة صامتة"، مجلة كلية

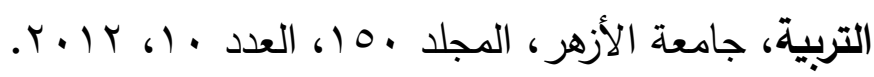

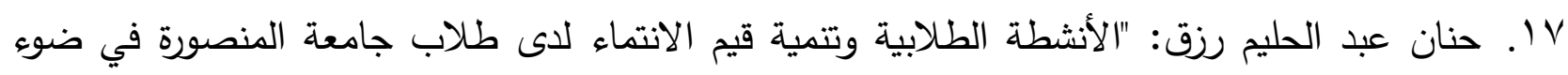

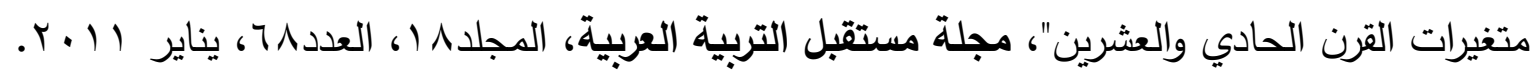

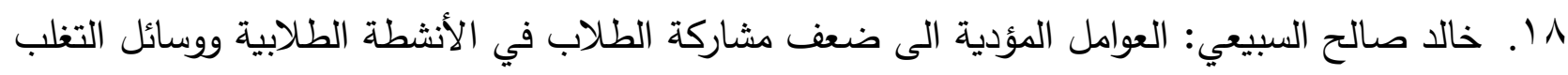

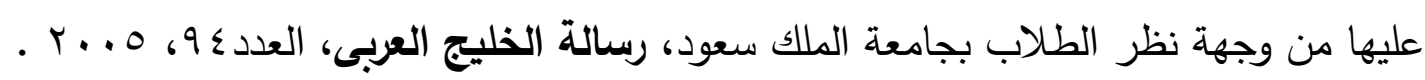

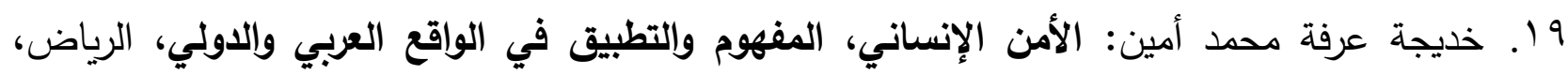

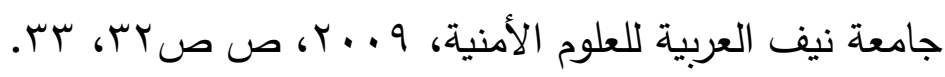

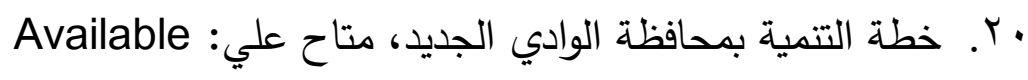
at:http://www.arabgeographers.net/up/uploads/pdf اr. درية السيد البنا: "واقع ممارسة الأنثطة التربوية الحرة بالمعاهد الأزهرية الثانوية"، مجلة كلية التربية،

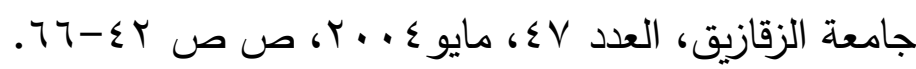

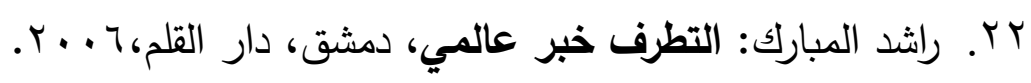

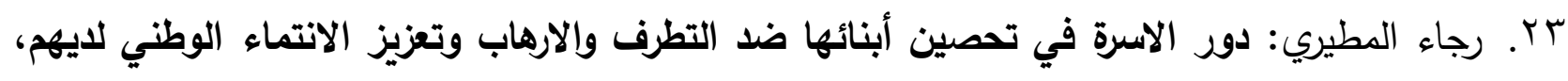

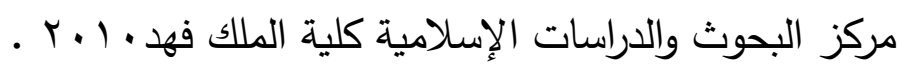
؟r. شاكر عبد الحميد: التفسير النفسي للتطرف والإرهاب، وحدة الدراسات المستقبلية بمكتبة الإسكندرية r. 17

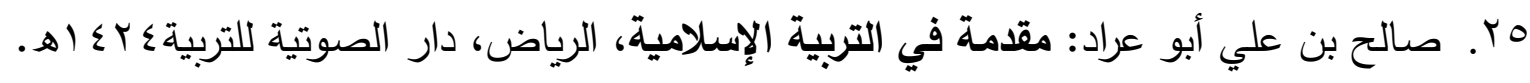

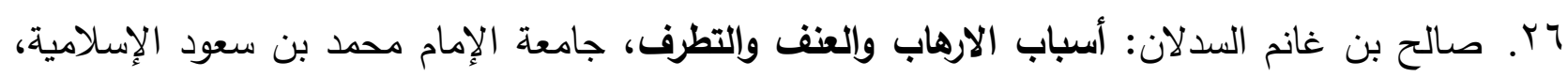
$.1 \leqslant T V$

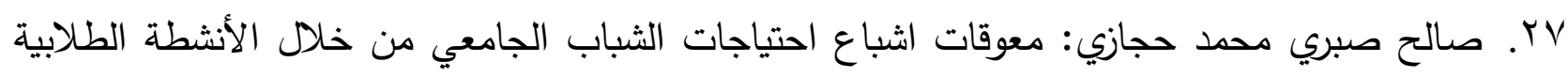
والتخطيط لمواجتها ( دراسة مطبقة علي بعض الكليات المستحدثة بتفهنا الاشراف)، رسالة ماجستير ،

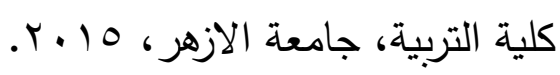

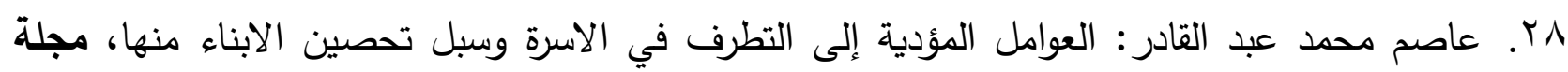

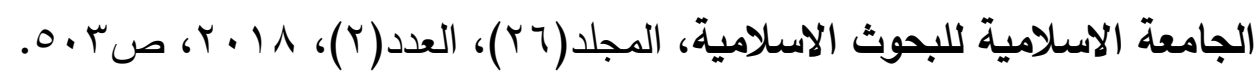

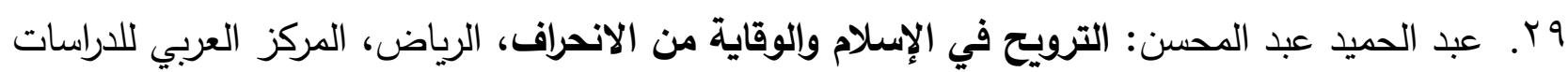

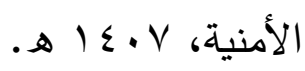


•r.r. على معمر عبد المؤمن: مناهج البحث في العلوم الاجتماعية" الأساسيات والتقنيات والأساليب، الإدارة

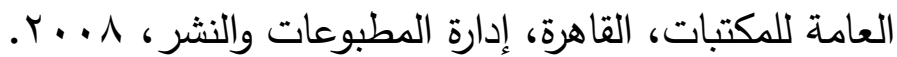
ابا. على هود بإعباد: دور الجامعات والمؤسسات التربوية والثقافية في تعزيز الوسطية بين الثباب، بصنعاء

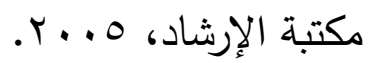

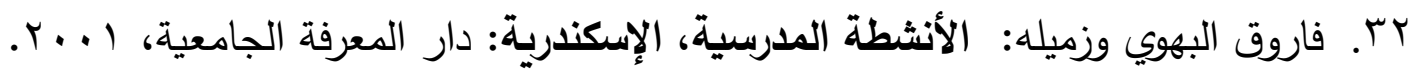

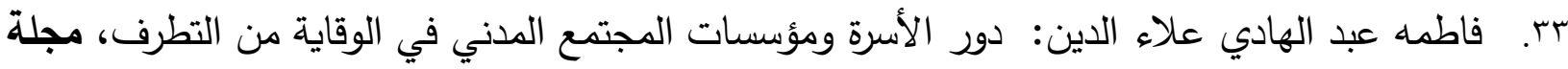

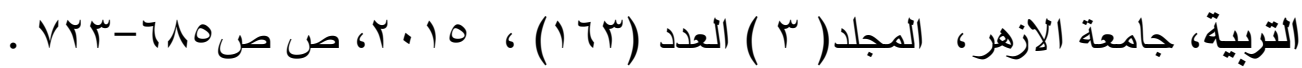

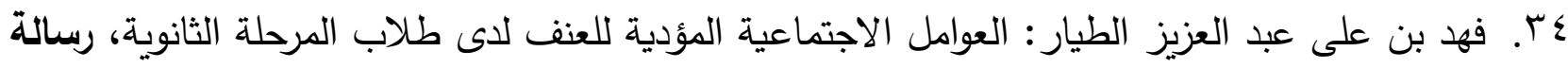

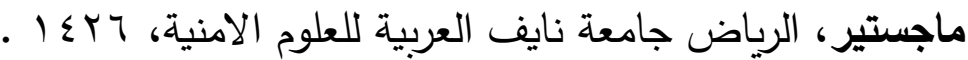

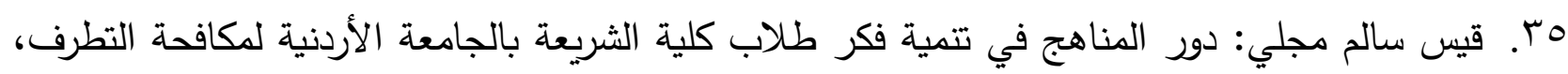

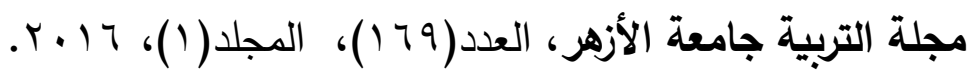

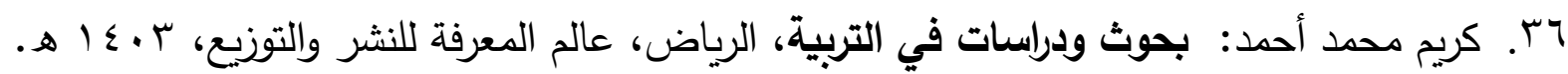

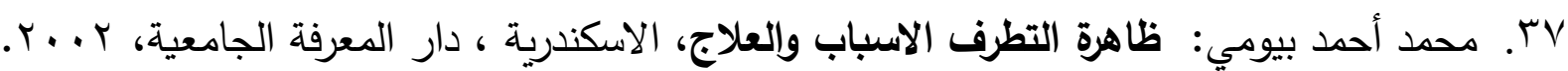

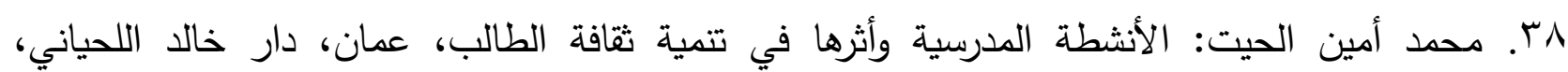
.17

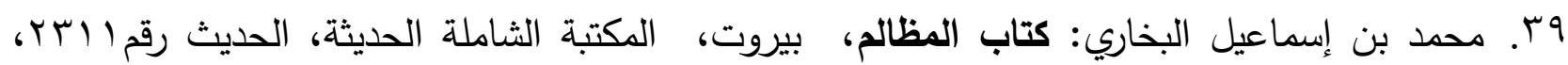
$.1 \leqslant r T$ •ـ. محمد بن إسماعيل البخاري، كتاب الرقاق، المغامسة، المكتبة الثاملة الحديثة، الحديث رقمجـ . ج، $.1 \mathrm{rov}$

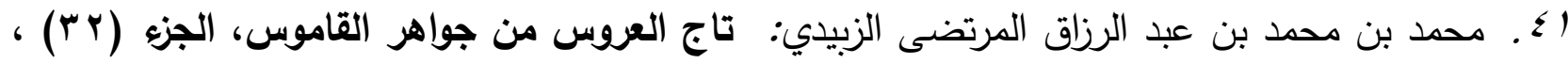

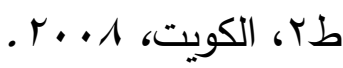
بــ. محمد عبد المولد الدقس: اتجاهات الثباب السعودي نحو ظاهرة التطرف الفكري، كلية الدراسات العليا،

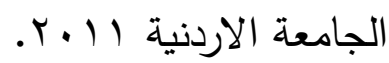

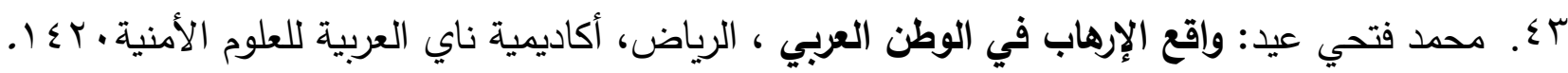

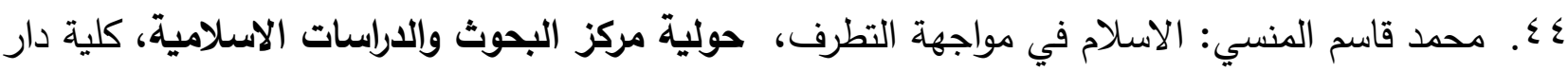

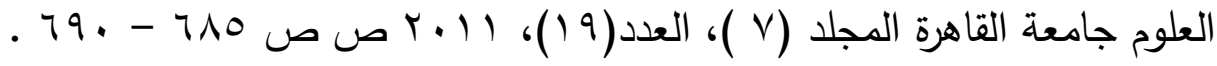

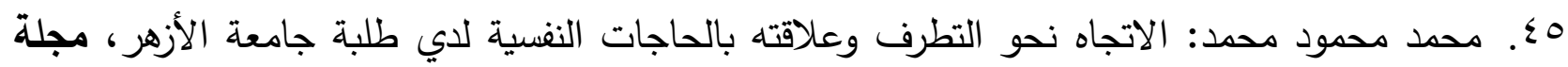

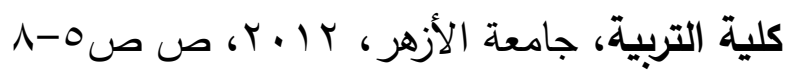

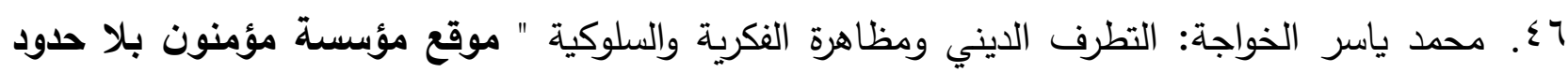

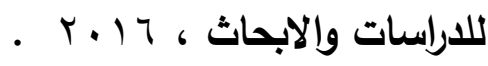


E V. . مصطفي عبد الحميد عناني: تفعيل دور الأنشطة الطلابية بكليات التربية فتمية قيم المواطنة العالمية

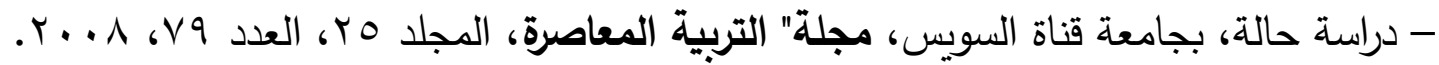
^ء. . منال بنت عمار : "الدور التربوي للأنشطة الطلابية في تنمية بعض المبادئ التربوية لدى طالبات المرحلة

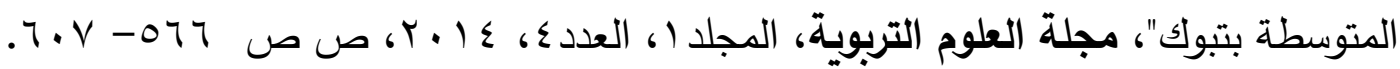
9ء. ناصر عبد الكريم العقل: الخوارج أول الفرق في تاريخ الإسلام، مناهجهم وأصولهم وسماتهم قديماً

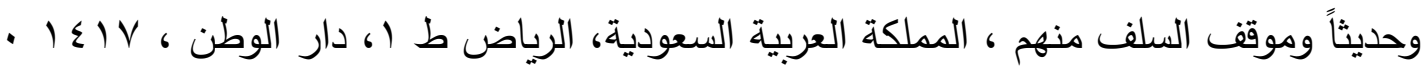
••. نورة محمد المناعي: العائد التربوي للأنشطة التربوية الاشكالية والحل، ورقة مقدمة الي المؤتمر الأول للأنشطة التربوية وزارة التربية والتعليم الامارات العربية المتحدة، ا ـ. . . .

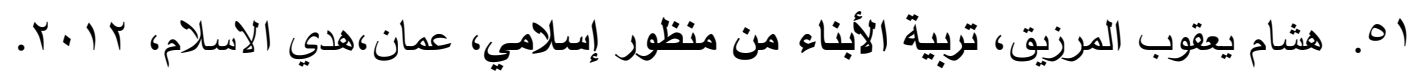

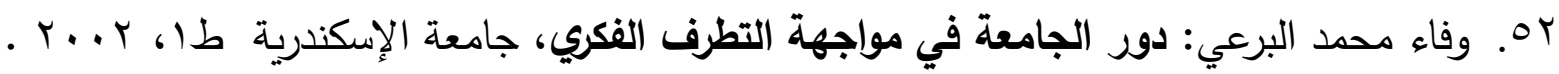
به. وليد بن عد العزيز يعد الخراشي: دور الأنشطة الطلابية في تتمية المسؤولية الاجتماعية، رسالة ماجستير، كلية الآداب، عمادة الدراسات العليا، جامعة الملك سعود، ؟ . . ؟. ثانياً المراجع الاجنبية

53. Arno Green, "An Unrecognized Pathology: The Mask of Humaneness Journal of Psychohistory, vol. 30, no.3 (Win 2003), pp. 266 - 272.

54. Bernd Simon \& Bert Klandermans "Politicized Collective Identity American Psychologist, vol. 56, no. 4 (2001), pp. 319 - 331.

55. Clark McCauley, "The Psychology of Group Identification and the Power of Ethnic Nationalism", In Daniel Chicot \& Martin E. P. Seligman (Eds.) Ethno-political Warfare: Causes, Consequences, and Possible Solutions (Washington, DC: American Psychological Association, (2001), p. 350.

56. Dagmar .M \& Tino W(2015). Evolving Lesson Plans to Assist Educators: From Paper-Based to Adaptive Lesson Planning, Journal of Health, Population and Nutrition, Vol. 2015.

57. Michael Wes sells Paper Presented Peace building Matters", , "Terrorism, Apocalyptic Ideology, and Young : Martyrs Why Paper Presented at The American Psychological Association Conference, Chicago, August( 2002).P154

58. Rider University Architects, Student Activities Center Alterations, University Architects, Lawrenceville, New Jersey,2016. 